\title{
Labour Reform in South Africa: Measuring Regulation and a Synthesis of Policy Suggestions
}

\author{
Haroon Bhorat \\ Halton Cheadle \\ Haroon.Bhorat@uct.ac.za
}

Development Policy Research Unit

DPRU Working Paper 09/139

September 2009

ISBN No.: 978-1-920055-74-5 


\section{Abstract}

Even though the South African economy is formally categorised as an upper-middle income country, it has one of the highest unemployment rates in the world. The economy's unemployment rate stands officially at 26.7 per cent and 38.8 per cent. This characteristic, more than any other, has placed market regulation high on the agenda of pertinent policy issues in South Africa. This paper, then, in trying to mature the debate on labour regulation and worker protection, has two key objectives. Firstly, we attempt to provide more nuanced and empirically-based measures of labour regulation and worker protection for South Africa, within an international comparative context. Secondly, we attempt a legal overview of some of the key legislative and institutional challenges that exist within the South African labour market.

We also attempt an overview of the evidence relating to the degree of actual and perceived rigidity within the South African labour market. The evidence utilised will hopefully add value to the debates thus far on the extent and nature of labour regulation in South Africa.

\section{Acknowledgement}

This Working Paper is one in a series eminating from the Critical Research Projects funded by the Department of Labour. This project was commissioned to the Development Policy Research Unit (headed by Prof, Haroon Bhorat at the University of Cape Town) and the Sociology of Work Unit (led by Prof. Eddie Webster at the University of the Witwatersrand) under the auspices of the Human Sciences Research Council (let by Andre Kraak).

The authors are Professor Haroon Bhorat at the School of Economics, University of Cape Town and Professor Halton Cheadle at the Faculty of Law at the University of Cape Town, Cape Town, South Africa

Development Policy Research Unit Tel: +27216505705 Fax: +27 216505711
Information about our Working Papers and other published titles are available on our website at:http://www.dpru.uct.ac.za/ 


\section{Table of Contents}

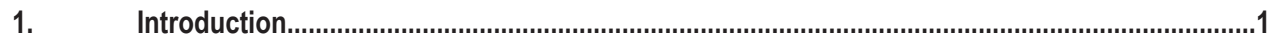

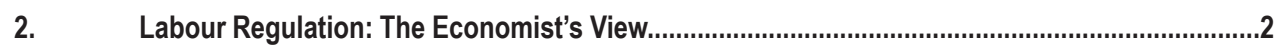

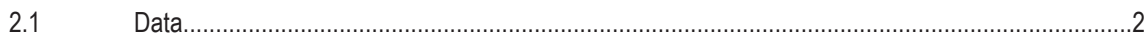

$2.2 \quad$ Labour Regulation and Worker Protection in the late 1990s....................................................

2.3 Labour Regulation and Worker Protection as a Cost of Doing Business ......................................11

2.4 Changing Levels of Regulation and Protection .....................................................................15

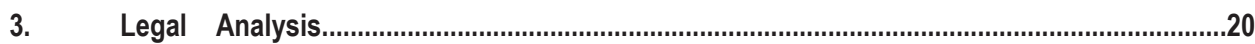

$3.1 \quad$ Approach to Regulatory Reform.........................................................................................

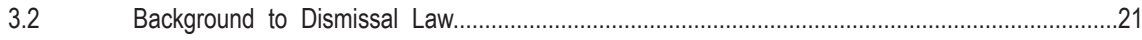

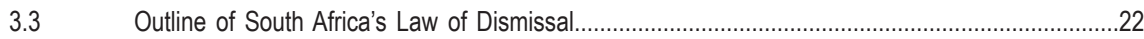

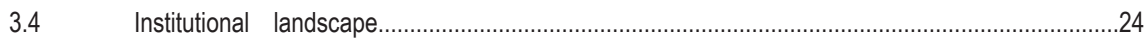

$3.5 \quad$ The Logic and Design of the LRA

3.6 Implementation of the Design..........................................................................................2

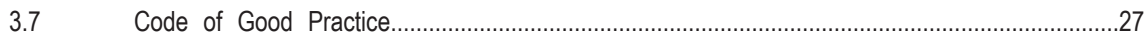

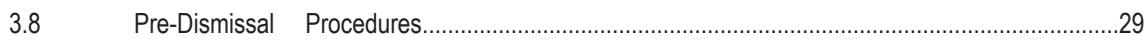

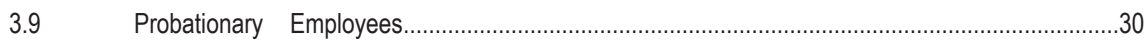

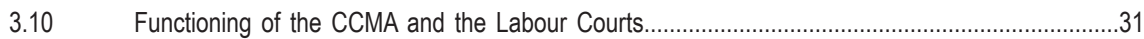

3.11 Dispute Resolution by Bargaining Councils and Private Agencies...............................................32

3.12 Weaknesses in the Design..............................................................................................3

3.13 Application of Dismissal Protection to Senior Management........................................................33

3.14 Application of Statuary Retrenchment Procedures to Small Businesses......................................34

3.15 Compensation for Procedural Unfairness.....................................................................34

3.16 Appellate Structure in Dismissal Disputes..........................................................................35

3.17 Reforming the Labout Market: A Synthesis of proposed Interventions...........................................35

3.18 Small Employers................................................................................................................

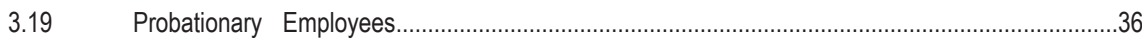

3.20 Senior Management and Ptofessional Employees...................................................................36

$3.21 \quad$ Code of Good Practice: Dismissal.....................................................................................

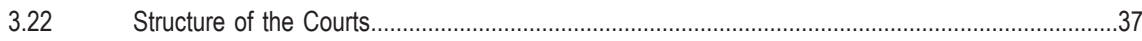

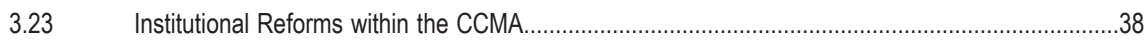

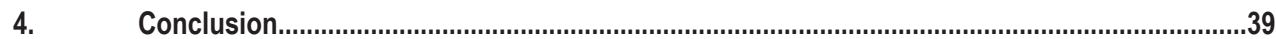

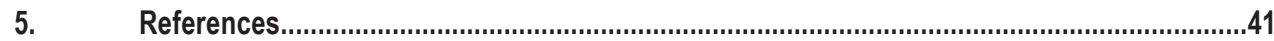

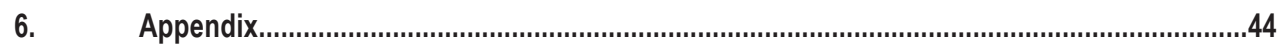




\section{Introduction}

Perhaps the most prominent welfare challenge facing post-apartheid South Africa is the economy's unemployment rate. It is an economy categorised formally as an upper middle income country but with one of the highest unemployment rates in the world - officially at 26.7 per cent (38.8 per cent if discouraged workers are included). This characteristic, more than any other, has placed labour market regulation high on the government's agenda. However, the controversial nature of the issues at stake and the highly organised nature of the social partners has meant that any change to the regulatory and institutional framework is a highly contested policy issue in South Africa.

This paper, in trying to advance the debate on labour market regulation and worker protection, has two key objectives. Firstly, we argue for a more nuanced and empirically-based measures of the intensity of labour regulation and worker protection in an international comparative context. Secondly, we provide a legal overview of some of the key legislative and institutional challenges that exist within the South African labour market together with a non-technical synthesis of the key legislative and institutional reform proposals that have arisen out of recent policy discussions within the country. The paper is accordingly a modest attempts to integrate economic and legal analyses of the South African labour market. This, as we will illustrate below, remains essential in order to feed into ongoing and at times vociferous debates around the nature and extent of regulation within the South African labour market. 


\section{Labour Regulation: The Economist's View}

It is necessary to provide an overview of the evidence relating to the degree of actual and perceived rigidity within the South African labour market in order to utilise that evidence to advance the debate on the extent and nature of labour regulation in South Africa and to provide an appropriate framework within which to appreciate and understand the nuances of the legal debates concerning regulation of the South African labour market discussed in the next part of this article.

The reliance in recent studies (Bhorat 2004; Chandra et al 2000; Devey et al 2005; Rankin 2006) on a limited number of firm survey datasets suffer from three key drawbacks': Firstly, the studies report on firms' perceptions regarding the labour legislative environment, rather than more objective measures of regulation. Secondly, most of the firm surveys do not contain sufficiently nuanced questions on the labour regulatory regime - rendering many of the results too blunt to constitute informed and effective measures of rigidity or flexibility. Finally, the studies are self-standing and, hence, are not easily compared with each other as between economies and over time. We hope deal with these drawbacks by using the evidence presented below to provide a more detailed and more objective assessment of the labour regulatory environment in South Africa and its comparative standing internationally.

\section{$2.1 \quad$ Data}

Two datasets are utilised in this section of the paper. There is firstly a composite, detailed cross-country dataset on different aspects of employment, collective relations law and social security legislation. It is a dataset compiled by Botero et al in a seminal study on the impact of labour regulation around the world (Botero et al 2004). The data covers 85 countries and is very deliberate in its construction of indices of labour regulation ${ }^{2}$ ranging from, for example, laws on overtime and part-time work to those on dismissals, notice periods and the right to strike activity and collective bargaining. The information is representative of country-level information for the late 1990s, and in most cases reflects data for 1997. It was, as far as is known, the first, and most comprehensive measure of labour regulation that is cross-country in

$1 \quad$ This refers essentially to the World Bank's Large Manufacturing Survey run in the late 1990s for the Greater Johannesburg Area, the South African Presidency's National Enterprise Survey and latterly the World Bank's repeat manufacturing survey for the Durban Metropole.

2 As the rest of the paper, in particular the issues around policy reform in the labour market, will indicate - while these measures are indeed deliberate they are not necessarily the most appropriate or the only indices of labour market regulation at a country-level. 
nature and not perception-based. ${ }^{3}$ Individual research teams, in addition to existing regulatory databases, were assigned the task of collecting and collating the information at the countrylevel.

The second dataset for the study is more recent and more widely known. Specifically, the use of the World Bank's Cost of Doing Business Survey (CDBS) for 2006. The survey has been ongoing since 2004, and covers approximately 175 countries. Its core function is to provide objective measures of the costs of business regulation within an economy. In what follows below, the focus is on the labour regulation module within the survey questionairre. It is crucial to note, however, that the methodology and approach within the CDBS has relied heavily on that of Botero et al (2004). ${ }^{4}$ The broad areas of labour regulation covered in the survey are those related to legislative provisions for hiring, firing and hours of work in the employment relationship. In addition legislative provisions for firing a worker and those related to non-wage costs are converted into a measure of the regulatory cost of hiring and firing workers. In contrast to the earlier Botero et al (2004) study, however, the CDBS relied on local firms of lawyers to glean the information on the labour regulatory regime.

The argument, in what follows, is to provide an empirical overview of the results for South Africa in relation to these two surveys. Also, despite the two datasets not being a perfect match - one undertaken in the late 1990s and the second in 2006 - we consider as some sort of repeated cross-section wherein appropriate comparisons around changing labour regulatory patterns could be gleaned. Whilst the survey questions, with regard to labour regulation, are very similar a few precautions are required when undertaking this comparative exercise. Firstly, although the underlying individual questions, which are aggregated up to produce the indices, are extremely closely matched across the two surveys there are differences in nuance and coverage. ${ }^{5}$ Secondly, the manner of collecting the information differs in the two surveys. As noted above, the 1997 survey used individual researchers combined with the relevant crosscountry databases. The World Bank's survey relied exclusively on the services of in-country law firms for the labour regulation module within the survey questionairre. It is in fact, the use

3 The Botero et al (2004) study assimilates much of the important, but ultimately partial, databases on labour regulation ranging from that contained in Forteza and Rama (2001) for the World Bank, the much-cited Heckman and Pages (2003) for Latin America \& the Caribbean and a variety of complementary databases under the auspices of the International Labour Organisation, OECD and World Bank. minor changes" (http://www.doingbusiness.org/MethodologySurveys/ ).

5 For example, the range of questions which make up the rigidity of hours index in the Botero et al (2004) study is far more extensive than that found in the CDBS. 
of the latter which has (at least in the South African context) resulted in some concern around the veracity of the estimates provided in the CDBS (See Benjamin 2006; van Niekerk 2006). Finally, although not completely insurmountable, it is not clear that each entry for the individual countries in the Botero et al study are for the same year. Hence it is entirely possible that the survey reflects estimates of labour regulation for countries in the 1990s, rather than specifically for 1997.

Despite important advances made in the Botero et al's methodology through increasing the granularity in measuring labour market regulation - two more broad objections and concerns need to be noted at the outset. Firstly, the range of different sub-indices utilised for hiring and firing, may exclude certain important measures of regulation. An obvious example is that of employment equity legislation. This is not included in any of the hiring regulation or hiring cost measures, and could potentially impact on the perceived or actual level of rigidity in an economy's labour market. The generic point, however, is that certain aspects of the regulatory regime, through not being featured within the sub-index measures may result in biased aggregate measures of labour regulation. A second key objection is more qualitative in nature. This is the fact that some legislative provisions which are implicitly viewed as regulatory in nature, are not generally regarded as such by legal practitioners. Perhaps the most powerful example of this, is the collective rights index within the Botero et al study. From a legal perspective the right to freedom of association (and with it the right to join a union) are universally recognised rights entrenched in public international law and in most if not all democratic constitutions. They constitute a fundamental human right and cannot therefore constitute a species of adaptable regulation. Indeed, as we note below, from a jurisprudential point of view the notion of a continuum ranging from 'flexible' to 'rigid' to characterise labour market regulation is problematic.

Despite these caveats, the approach we follow is to individually analyse both datasets first and then to complete the analysis with a comparison of how South Africa's labour regulatory regime in an international context, has altered since the mid-1990s.

\subsection{Labour Regulation and Worker Protection in the late 1990s}

In attempting to provide empirically robust measures of labour regulation for South Africa, together with an international comparison, the data below adds significant value to recent work in the area. Table 1 thus presents measures of labour regulation and social security \& health for 85 economies around the world for the late 1990s, presented as the mean by broad 
country income level. Within these measures of worker protection and labour regulation, three broad categories arise: The first category concerns the regulation of the individual employment relationship such as the regulation of working time, leave, dismissals and redundancies.. The second category concerns the regulatory framework governing collective labour relations such as freedom of association, recognition of trade unions, collective agreements and the right to strike, recognition of trade unions and collective agreements. The third category concerns social protection such as health and unemployment insurance and other non-wage benefits. In most cases, the source of information for compiling the different indices emanate from the legislative provisions of the individual economies. Hence, the database serves as an attempt at interrogating the labour and other legislation within a country and converting its relevant components into a measurable ranking of rigidity or protection. ${ }^{6}$ These measures are typically normalised to vary between 0 and 1 , where higher values denote higher levels of regulation or protection.

A detailed overview of the derivation of the individual mean measures for the Botero et al (2004) dataset is provided in Appendix A1. However, it is important to provide some sense of how these estimates were derived. If we take, for example, the case of the dismissal procedures noted in Table 1: The variable provided is an average of seven dummy variables which try and capture the different labour legislative provisions related to dismissals. As the Appendix A1 will elucidate in greater detail, if the law stipulates that an employer must notify a third party in the case of a collective dismissal, ${ }^{7}$ then the country records a value of 1 , and if not, a value of 0 . If there are priority rules for re-employment, which give first preference to workers made redundant, then the country records a value of 1 and if not, a value of 0 . The remaining variables that constitute the dismissals procedure index, are thus compiled in a similar manner. The average of these seven dummy variables is then presented as an estimate for dismissal procedures in a country. The data illustrates that economies such as Malaysia, Singapore, Bolivia, Uruguay and Zambia record a zero on dismissal procedures - while France, India, Mexico and Peru record values greater than 0.8. Almost all variables constructed in Table 1, are numerical indices derived from the prevalent legislation in the country. This dataset is, therefore, as alluded to above, an attempt at converting legislative

6 Specifically, then, for South Africa, these measures for labour regulation would be gleaned from the Labour Relations Act (LRA) and the Basic Conditions of Employment Act (BCEA). The specificities of the legislation (in particular the LRA) which focused labour regulation debates in South Africa are dealt with in Section 3.

7 'Collective dismissals' is the term used in other comparative jurisdictions for what is called in South African law dismissal for reasons relating to the operational requirements of the enterprise. 
provisions and stipulations into a consistent, comparable and perhaps most importantly measurable - index of labour market protection.

Table 1: Average Measures of Labour Regulation in the late 1990s, by Country Income Level

\begin{tabular}{lccccccc}
\hline Area of Regulation/Income Level & $\begin{array}{c}\text { Low } \\
\text { Income }\end{array}$ & LMI & UMI & $\begin{array}{c}\text { HI - non } \\
\text { OECD }\end{array}$ & HI - OECD & South Africa & Total \\
\hline Alternative Employment Contracts & 0.528 & 0.622 & 0.637 & 0.629 & 0.631 & 0.250 & 0.608 \\
Cost of Increasing Overtime & 0.290 & 0.400 & 0.451 & 0.648 & 0.270 & 0.156 & 0.445 \\
Firing Costs & 0.445 & 0.534 & 0.507 & 0.392 & 0.437 & 0.511 & 0.467 \\
Dismissals Procedures & 0.460 & 0.510 & 0.406 & 0.390 & 0.229 & 0.143 & 0.429 \\
\hline Aggregate Employment Law Index & 0.431 & 0.517 & 0.500 & 0.515 & 0.392 & 0.265 & 0.487 \\
\hline Labour Union Power & 0.348 & 0.422 & 0.489 & 0.463 & 0.305 & 0.714 & 0.425 \\
Collective Disputes & 0.431 & 0.504 & 0.465 & 0.456 & 0.458 & 0.333 & 0.465 \\
\hline Aggregate Collective Relations & 0.389 & 0.463 & 0.477 & 0.460 & 0.382 & 0.524 & 0.445 \\
Index & & & & & & & \\
\hline Labour Regulation Index & 0.410 & 0.490 & 0.489 & 0.487 & 0.387 & 0.394 & 0.466 \\
\hline Old Age, Disability \& Death & 0.445 & 0.571 & 0.543 & 0.692 & 0.668 & 0.342 & 0.575 \\
Benefits & & & & & & & \\
Sickness \& Health Benefits & 0.384 & 0.598 & 0.761 & 0.747 & 0.822 & 0.611 & 0.641 \\
Unemployment Insurance & 0.090 & 0.376 & 0.625 & 0.773 & 0.668 & 0.773 & 0.491 \\
\hline Aggregate Social Security Index & 0.306 & 0.515 & 0.643 & 0.737 & 0.719 & 0.575 & 0.569 \\
\hline Aggregate Protection & 0.339 & 0.482 & 0.536 & 0.610 & 0.527 & 0.476 & 0.499 \\
\hline
\end{tabular}

Source: Dataset compiled by Botero et al, 2004 and Authors' Own Calculations

Notes: $\quad$ 'LMI' refers to Lower Middle-Income countries; UMI to Upper-Middle Income countries and HI to High Income economies either within the OECD or not. These are standard classification drawn from the World Bank's World Development Report (2005) All indices are normalised to one, with the italicised, composite indices an arithmetic mean of the preceding sub-indices. In turn the final aggregate protection index, is an overall mean of the labour regulation and the aggregate social security index.

According to the World Bank's country income classification method, various forms of labour regulation are derived. In terms of both individual employment and collective relations legislation, it is evident that according to this dataset for the late 1990s, the highest levels of regulation are found in the cohort of middle-income economies. Hence, apart from the overtime sub-index, the highest levels of regulation tend to be located within the cohort of lower-middle or upper-middle income countries. Notably, however, in some cases, the measure of labour regulation in non-OECD high income economies approximates that measured for middle-income countries. The important exception, apart from overtime, is that of firing costs. In the latter case, the firing costs of non-OECD high-income economies is the lowest in the sample. There is a concern of course, that high dispersion in values across countries may impact on the results. However, when median values are used, instead of the mean, the broad results holds true. While the overall labour regulation index thus appears 
to be the highest amongst the cohort of middle income (and to some extent, high-income non-OECD) economies - in the case of social protection, the results differ significantly. Hence, across the various social protection measures, high-income economies in general afford higher levels of protection to employees in respect of health, aged and unemployment benefits.

Of greater importance, within the context of this paper, are the regulatory measures calculated for South Africa. Classified as an upper-middle income country, the comparisons across the regulatory indices are surprising. In the first instance, it is evident that South Africa's measures of labour regulation, compare quite favourably with those found in the rest of the world. In almost all of the individual regulatory sub-indices, South Africa yields a level of regulation that is lower than both the mean for upper-middle income countries, and for the sample of countries as a whole. For example, in the case of alternative employment contracts the legislative regime governing part-time work, contractual employment and so on - South Africa yields an extremely low measure of labour regulation. This is in part, confirmed by the legal analysis to follow. Indeed, one of the key features of the post-apartheid South African labour market has indeed been the rapid increase in atypical forms of employment (see Bhorat \& Hinks 2005; Poswell, Lundall \& Naidoo 2004; Godfrey \& Theron 2004) - with its incidence uneven at the main sector level and its dominance amongst younger workers. It is accordingly at least arguable that the fairly flexible legislation governing these types of individual employment arrangements has contributed to the rapid growth of non-permanent employment in the labour market in post apartheid South Africa The upshot of these individual indices, is that the aggregate labour regulation and aggregate protection indices for South Africa remain fairly low in international terms. However, there are three important exceptions to the fairly standard levels of regulation found for South Africa in the late 1990s. These are in the areas of firing costs, labour union power and the provision of unemployment insurance. In each of these cases, South Africa yields measures that are higher than both the upper-middle income country mean and the estimate for the sample as a whole.

Given the above point estimates, however, it is useful to provide a more nuanced assessment of South Africa's specific ranking in the global distribution of labour regulation and social protection measures. Hence, in Figures 1-3 we examine the percentile distributions of regulation and protection, differentially measured, and determine where South Africa should be positioned. The global distributions are presented in the main text, while the estimates for the sample of upper-middle income economies, are found in the Appendix. Hence, Figure 1 presents the percentile distribution across the 85 countries in the sample, for three labour regulation indices, namely the employment 
law index; the collective relations index and the labour regulation index. The lastmentioned is the average of the first two indices. South Africa is represented by the icon placed at the specific point in the distribution where its measure is located.

Figure 1: Employment Law Collective Relations and Composite Labour Regulation Index Cross-Country Percentile Distribution and South Africa

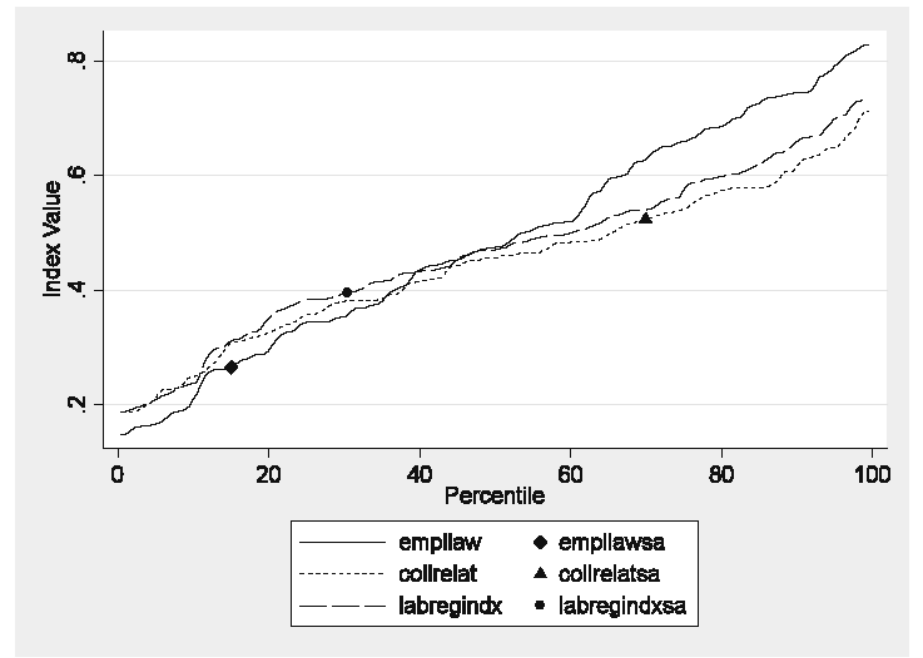

Source: $\quad$ Based on Botero et al 2004 and Authors' Own Calculations

The data is visually striking. In the first instance, then, it indicates that South Africa in terms of its employment law index (the variables empllaw and empllawsa), reflects a composite value at the low end of the global distribution. Specifically, South Africa's employment index value of 0.265 , places it for the late $1990 \mathrm{~s}$, at the $15^{\text {th }}$ percentile of the global distribution for the protection and regulation of individual employment rights. In terms of the collective relations index (collrelat and collrelatsa), however, it is evident that South Africa yields a fairly high level of regulation in international terms. Hence, the measure broadly of union power and the protection of collective rights (at a value of 0.524 ) positions South Africa at the $70^{\text {th }}$ percentile of the international distribution. The combination of the two indices - the mean of the individual employment and collective rights indices - is represented by the labour regulation index (labregindx and labregindxsa). In this case, South Africa's index value of 0.394 , positions the economy at the $30^{\text {th }}$ percentile in the global distribution of labour regulation.

In trying to present an overall index of regulation that encompasses both labour market and social security regulation - Figure 2 presents these two indices and then a third aggregate protection measure measured simply as the mean of the former two. It is evident that relative 
to labour market regulation, South Africa yields greater levels of protection in terms of social security.

Figure 2: Labour Regulation and Social Security Indices and Aggregate Protection Index Cross-Country Percentile Distribution and South Africa

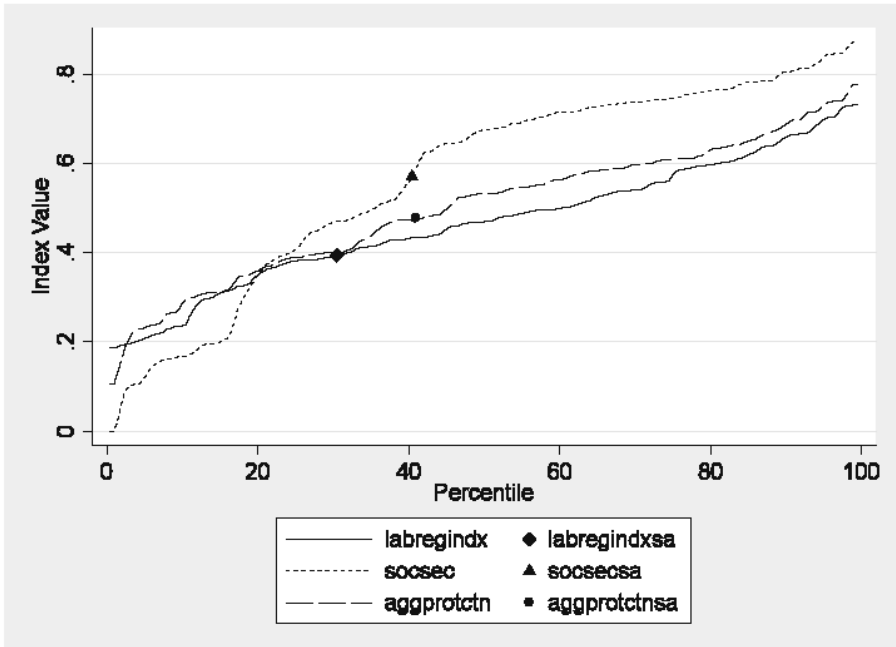

Source: Based on Botero et al 2004 and Authors' Own Calculations

Hence, the social protection index, at 0.575 , ranks South Africa at the $40^{\text {th }}$ percentile of the global distribution. The combined aggregate protection index, at 0.476 for South Africa yields a global ranking at the $41^{\text {st }}$ percentile.

It may be useful, as a final cut on this data for 1997, to examine the three measures that appear to be significantly higher than others, in terms of protection and labour regulation, for South Africa. Hence, in Figure 3 the firing costs, the index of union power and the provision of unemployment insurance are isolated. South Africa places at the $45^{\text {th }}$ percentile for firing costs, $92^{\text {nd }}$ for union power and $64^{\text {th }}$ for unemployment insurance. 
Figure 3: Firing Costs, Union Power and Unemployment Insurance: Cross-country Percentile Distribution in South Africa

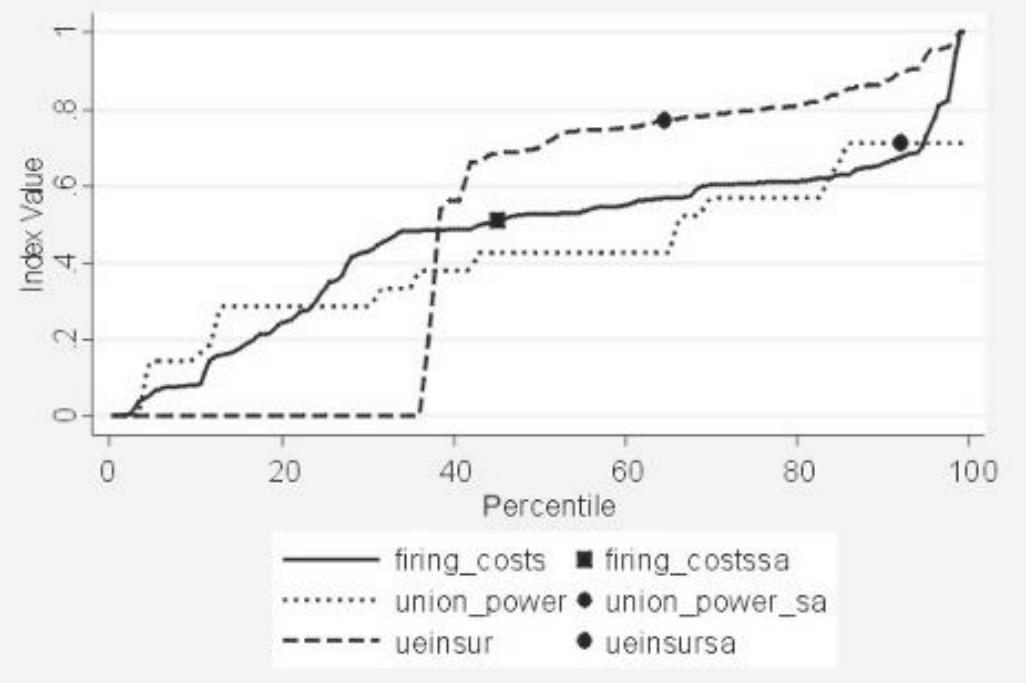

Source: $\quad$ Based on Botero et al 2004 and Authors' Own Calculations

It is clear then that, with the exception of labour union power, the individual measures that appear to be higher than others for South Africa, are not unusually excessive in these crosscountry comparisons. Furthermore, this evidence is stronger when the sample of upper-middle income economies only is examined.

From the above data for 1997, therefore, a number of preliminary conclusions regarding South Africa's regulatory and social protection environment can be gleaned. These are firstly, that South Africa has relatively low levels of regulation with regard to individual employment relations. While this is counterpoised by higher levels of regulation in terms of collective rights, the upshot is an overall regulation index which places South Africa in the bottom one-third of the global distribution of labour market regulation. Thirdly, South Africa yields higher levels of worker protection relative to labour regulation, resulting in a composite regulatory index that positions the economy in the $4^{\text {th }}$ decile of the global distribution of worker protection and labour regulation. Finally, in terms of the more specific measures that appear to be high for South Africa, it is labour union power which is extremely high. In the legal analysis we argue that freedom of association and collective bargaining embedded in this measure, should not be subject to notions of 'rigidity' or 'flexibility' within a labour market because such regulation is premised on universal human rights entrenched in international law and constitutional law and accordingly as a matter of regulation not capable of being removed. Ultimately then, on the basis of the above evidence for 1997, in international comparative terms and within the 
context of assigning values to legislative provisions and stipulations, South Africa cannot in any categorical way said to have an overly regulated or protected labour market.

The relevant year for this dataset, reflects on the legislation as it was promulgated through the intensive process of negotiation between employer bodies and union federations in the early 1990s. By the late 1990s there was a push within government to re-examine this legislation. Notably, one of the early policy statements made by President Mbeki in his first term, revolved precisely around examining, and possibly removing, those aspects of labour legislation that could be construed as harmful to employment creation (see Benjamin, 2006). It is often claimed that the accepted amendments which were published in 2002, were vastly different from their original conception. Importantly for our purposes here though, a more recent dataset, namely the Cost of Doing Business Survey for 2006, which by virtue of its timing will illustrate how South Africa's position in the distribution of regulatory and protection measures had altered (if at all). In part, of course, any changes could be seen as a function of the 2002 amendments, although given the nature of data and the lack of an appropriate set of covariates, the impact of the 2002 amendments cannot be accurately measured.

\subsection{Labour Regulation and Worker Protection as a Cost of Doing Business}

The CDBS is more recent and its labour regulation module is based very closely on the methodology of the Botero et al (2004) study. In addition, the CDBS is the most recent, and indeed possibly the most widely used, measure of labour regulation and worker protection within an international context. Hence, despite some of the reservations expressed regarding the CDBS, it remains a central information base for policy makers and investors alike. ${ }^{8}$

Table 2 presents the key measures available to the public user, from the dataset. Once again the data is presented by country income level. The difficulty of hiring index measures restrictions on part-time and temporary contracts, together with the wages of trainees relative

8 It should be noted that the detailed measures which together aggregate up to the five presented in this table, while explained in the metadata, but not available for download in their raw form, are obtainable through a special request to the World Bank. This more textured data is in fact essential for a more detailed analysis of regulation and protection at the country and cross-country level. Importantly for our purposes here, a close examination of the sub-indices that make up the overall index reveals a fairly accurate estimation of South African legislation by the law firms ultimately contracted by the World Bank. 
to worker value-added. ${ }^{9}$ The rigidity of hours measures the various restrictions around weekend, Sunday, public holiday work, as well as the limits on overtime and so on. The firing index, very closely resembles this dataset, in that the specific redundancy clauses within the legislation are examined and ranked. What the CDBS refers to as hiring costs, are in effect social protection costs and, hence, measure all social security and health costs associated with hiring a worker. Finally, the cost of firing, measures the costs of terminating the employment of an individual in terms of legislated notice period requirements, severance pay and so on.

Table 2: Mean Measures of Regulation, by Income Level

\begin{tabular}{lccccccc}
\hline Area of Regulation & Low Income & LMI & UMI & $\begin{array}{c}\text { HI - non } \\
\text { OECD }\end{array}$ & HI - OECD & South Africa & Total \\
\hline Rigidity of Hiring & 44.28 & 33.68 & 29.91 & 27.00 & 20.60 & 44.00 & 34.33 \\
Rigidity of Hours & 47.60 & 39.64 & 40.57 & 45.22 & 32.00 & 40.00 & 42.40 \\
Rigidity of Firing & 40.00 & 33.04 & 33.43 & 27.39 & 14.00 & 40.00 & 33.26 \\
Aggregate Employment Index & 43.96 & 35.45 & 34.64 & 33.20 & 22.20 & 41.33 & 36.66 \\
Hiring Costs & 12.40 & 16.01 & 17.31 & 21.43 & 10.17 & 2.40 & 15.62 \\
Firing Costs & 65.32 & 50.91 & 44.63 & 31.32 & 54.64 & 24.00 & 51.34 \\
\hline
\end{tabular}

Source: $\quad$ Cost of Doing Business, 2006 and Authors' Own Calculations

Notes: 'LMI' refers to Lower- Middle Income countries; UMI to Upper-Middle Income countries and HI to High-Income economies either within the OECD or not. These are standard classification drawn from the World Bank's World Development Report (2005) All indices are normalised to one hundred, with the italicised, composite indices the arithmetic mean of the preceding sub-indices.

From the aggregate cross-country data, there is an interesting bifurcation in the regulation and protection measures. Hence, the data indicates that the highest measures for any area of rigidity relating to regulation in hiring, firing and hours of work are found in low-income economies. This is, of course, in contrast to the Botero et al results which indicated the highest levels of regulation in the cohort of middle-income economies. In addition, however, the data show that firing costs are also the highest amongst low-income countries, although notably hiring costs are the highest in non-OECD high-income economies.

A glance at the values for South Africa indicates that, while hiring and firing costs, together with the hours rigidity index are below the global average, it is the hiring and firing rigidity measures

$9 \quad$ Herein lies one of the concerns, raised earlier, regarding the choice of sub-indices to derive an aggregate index. Hence, we find that on the measure of hiring rigidity, South Africa scores 0 on the first sub-indicator (there is no limitation on the use of fixed term contracts); 0 on the second (there is no maximum cumulative duration for fixed term contracts). That leaves the ratio of an apprentice's wages to average added value per worker as the third sub-indicator. In essence, therefore, the measure of hiring rigidity for South Africa is a measure of entry-level wages relative labour productivity - an inadequate representation of hiring rigidity. AS Section 3 confirms, South Africa yields fairly low levels of regulation around contractual employment. 
which are noticeably above the world mean. The possible areas within the legislation which could be deemed as problematic, or having unintended consequences within these latter two areas are therefore raised in detail in the sections below. However, similar to the above approach, in Figures 4-5, the country's specific position according to each of the indices is examined - in the global percentile distribution of protection and labour regulation. Figure 4 , therefore, presents the global distribution, across 175 countries, of rigidity in hiring, hours of work and firing. It is South Africa's hiring and firing rigidity, in corroboration with the mean results above, which on this more recent data, are positioned fairly high in the distribution: the economy is thus positioned at the $65^{\text {th }}$ percentile for hiring rigidity and at about the $60^{\text {th }}$ percentile for the difficulty of firing index. In addition, in comparison with upper-middle country sample, South Africa ranks at the $73^{\text {rd }}$ percentile for difficulty in hiring, and at the $63^{\text {rd }}$ for firing rigidity.

Figure 4: Hiring Hours and Firing Rigidity Cross-Country Percentile Distribution and South Africa

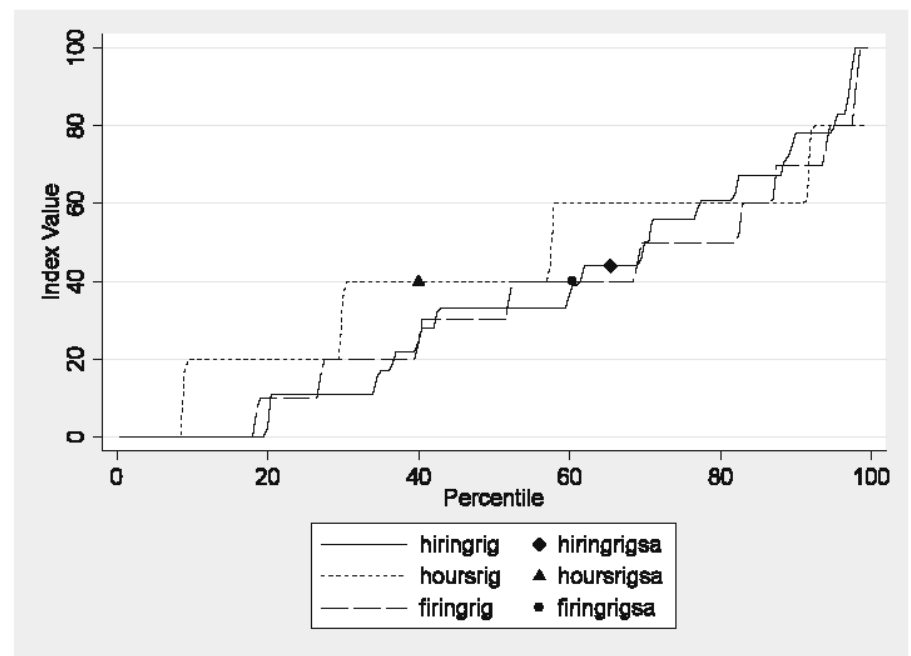

Source: $\quad$ Cost of Doing Business, 2006 and Authors' Own Calculations

It must be noted, however, that despite the above, in terms of the regulation governing hours of work, however, South Africa ranks at about the $40^{\text {th }}$ percentile in global terms.

Figure 5 examines the percentile distributions for the aggregate employment regulation index, and then hiring and firing costs estimates. Visually, it is very clear that in terms of hiring and firing costs, South Africa remains both fairly flexible and relatively low. Worker protection in the form of social security, therefore, positions South Africa at the $10^{\text {th }}$ percentile of the global distribution. Firing costs, which in effect measure the notice period and severance pay for a 
worker with specific characteristics, are also fairly low in international terms. South Africa's index value of 24 , thus places it in the bottom third of the distribution - specifically at the $30^{\text {th }}$ percentile.

Figure 5: Hiring and Firing Costs and Employment Regulation Cross-Country Percentile Distribution and South Africa

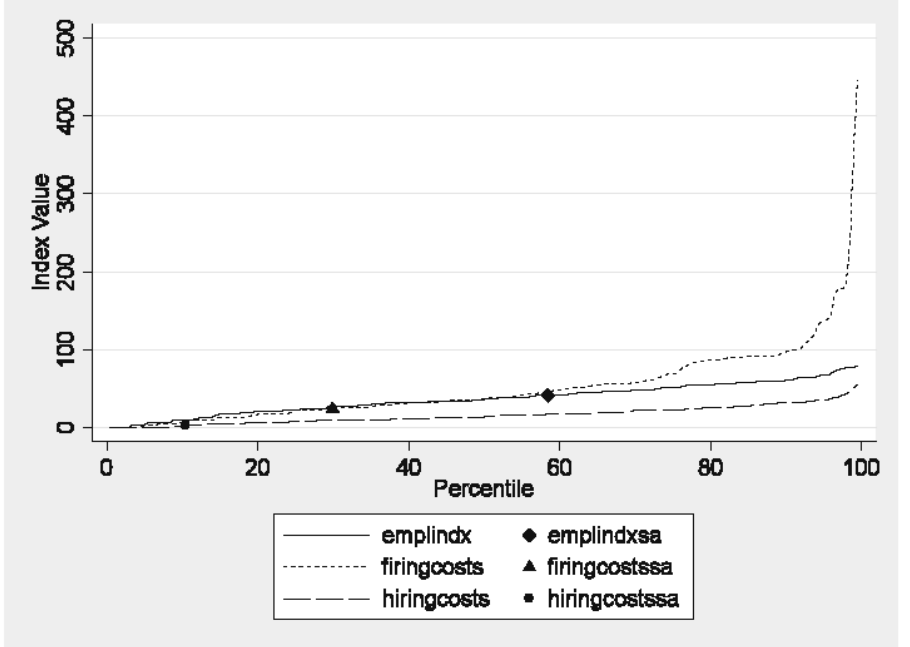

Source: $\quad$ Cost of Doing Business, 2006 and Authors' Own Calculations

Simply put, the legislative provisions for retrenching a worker yield a labour market that, according to 2006 data, is fairly flexible in terms of firing costs. The relatively high values for the regulation in hiring and firing, however, ultimately result in an employment regulation index that lies in contrast to the low hiring and firing costs. Hence, the finding is that, for the employment index, South Africa ranks at the $58^{\text {th }}$ percentile for the global sample. It is worth reiterating that this employment regulation index measures legislative provisions on work arrangements such as temporary tasks, the maximum duration for retaining short-term contracts, whether an employer needs to notify a third party in a retrenchment, reassignment and retraining rules during a retrenchment and so on. In this context, then, these measures are very specific about which components of the legislative environment are in fact considered to be inimical to employment creation. In our legal analysis we engage in a more detailed, nuanced assessment of whether and where such unduly high levels of protection may have occurred.

This more recent analysis of South Africa's labour market regulation - measured by a combination of employment inflexibility and social protection - indicates, therefore, an overall level of hiring and firing costs that is low by world standards. In contrast, however, it is clear 
that in the case of legislative provisions for firing workers and (due to the problems with the measure noted above) less so for hiring provisions, South Africa possesses a particularly high level of regulation. The legal analysis to follow will re-affirm this, given the focus on dismissal clauses, but will also implicitly note the centrality of effectively functioning labour market institutions. This is an important value-added to previous research in the area for South Africa, in that it suggests for the first time - at least according to empirical evidence here - where the reported rigidity within the domestic labour market may in fact lie. The data presented here, therefore, suggests that in the current environment, and on the basis of estimating legislative provisions primarily, any notion of lack of flexibility within the South African labour market lies specifically within the areas of hiring and firing provisions. Legislation that currently governs fixed-term contracts and the clauses governing dismissals and unfair labour practice ${ }^{10}$ are, according to the evidence presented here and corroborated in more detail in Section 3, at the heart of the labour market flexibility debate in South Africa.

\subsection{Changing Levels of Regulation and Protection}

The above has of course presented two discrete pieces of evidence, drawing on very similar datasets covering two time periods. It may be useful, however, to treat - given the cautionary notes above - the two datasets as some sort of repeated cross-section. Hence, in the data that follow, the more restrictive sample within the Botero et al study is retained, in order to ensure that shifts in South Africa's comparative regulatory and protection measures are being captured with the same sample of countries. ${ }^{11}$ The South Africa's position in the international distribution of hiring and firing rigidity as well as hiring and firing costs are then considered. In terms of the Botero et al definitions and terminology this involves examining alternative employment contracts (hiring rigidity), dismissal clauses (rigidity in firing), hiring costs (social security protection) and financial and legislative provisions for retrenching workers (firing costs).

The data presented in Figure 6 on hiring and firing rigidity (as well as those on costs noted below) indicates a surprising and significant shift in South Africa's position in the percentile distribution of this measure of regulation. Hence, it is clear that while both hiring and firing rigidity were below the $20^{\text {th }}$ percentile of the global distribution in the late 1990 s (hiringrig 97 and firingrig97), by 2006 this had altered dramatically (hiringrig06 and firingrig06).

\footnotetext{
10 Unfair dismissals and unfair labour practices as well as issues relating to probation, transfer of business ownership, promotion and so on are dealt with in Chapter VIII of the LRA, ss185-197.

11 Ultimately, with the Botero et al sample of 85 countries, the merged dataset yielded 79 economies found in both datasets.
} 
Figure 6: Hiring and Firing Rigidity - 1997 and 2006 Cross-Country Percentile Distribution and South Africa

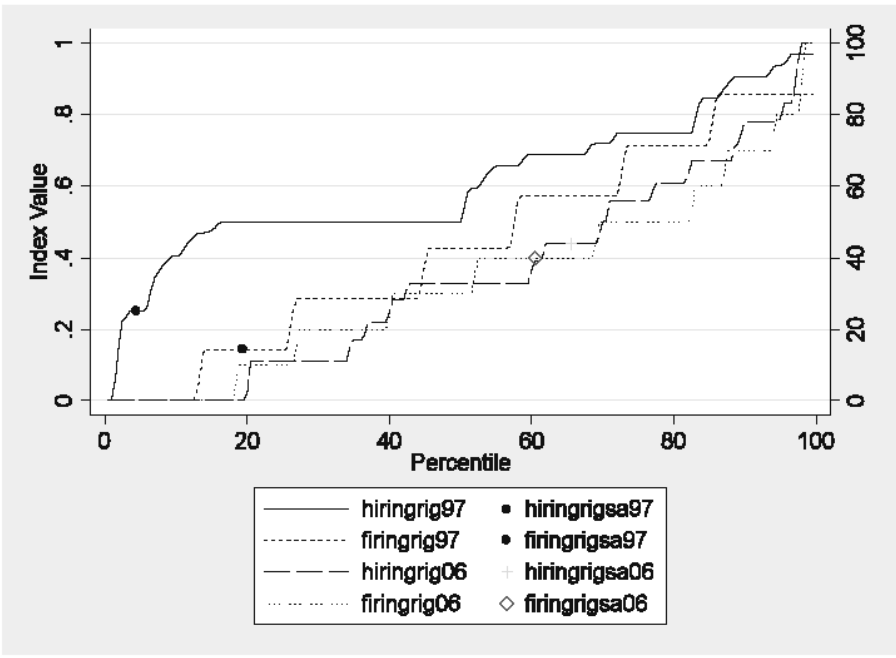

Source: Based on Botero et al 2004, CDBS 2006 and Authors' Own Calculations

Indeed, according to this CDBS-based data - the regulations dealing with issues such as the maximum cumulative duration of contracts; part-time contracts; retrenchment rules, conditions and stipulations - together yielded a labour market that in 2006 ranked above the $60^{\text {th }}$ percentile of the global distribution. In terms of hiring and firing costs, the converse pattern is observed. Hence, as Figure 7 confirms, while South Africa according to the Botero et al (2004) data was a high-cost labour market, by 2006 its position in the global percentile distributions had altered dramatically. 
Figure 7: Hiring and Firing Costs - 1997 and 2006: Cross-Country Percentile Distribution and South Africa

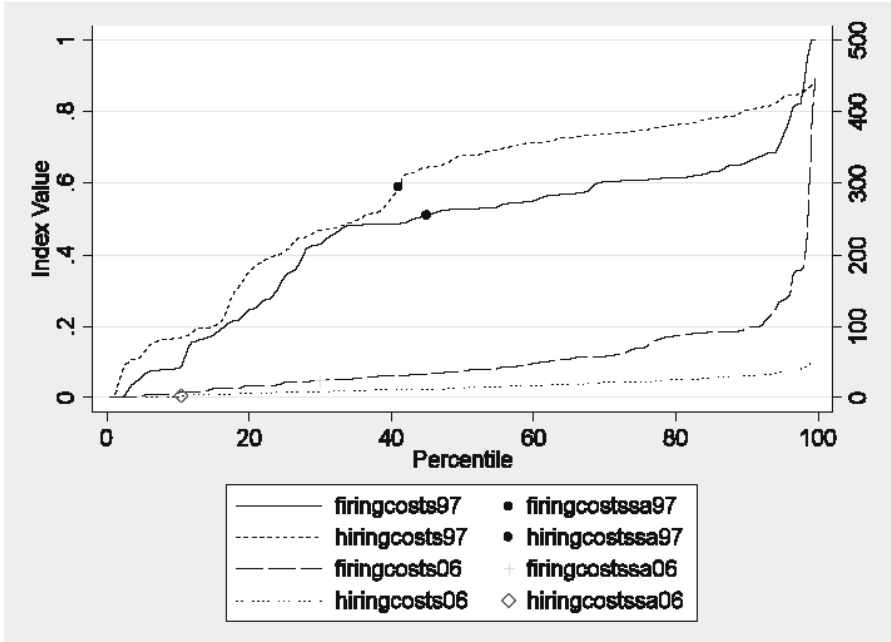

Source: Based on Botero et al 2004, CDBS 2006 and Authors' Own Calculations

Thus, data for 2006 indicates that South Africa was in the bottom one-third of this global distribution. Notably, hiring costs in South Africa were deemed to be the most flexible component, in a comparative sense, of the economy's legislative arrangements.

The combined evidence for the mid-1990s and 2006 suggests the following. While hiring and firing costs on the one hand and hiring and firing rigidity on the other hand were fairly rigid and flexible respectively in the late 1990s - by 2006 these rankings had reversed. Hence, with the current data here, the conclusion on the South African labour regulatory environment is that there is a high level of hiring and firing rigidity, combined, however, with a significant flexibility in terms of hiring and firing costs. Indeed, if these four measures are combined into one aggregate measure of labour market regulation, South Africa ranked at the $14^{\text {th }}$ percentile in the late 1990s. By 2006, South Africa ranked at the $39^{\text {th }}$ percentile. Overall then, through a combination of factors, one of which was possibly the 2002 amendment process, South Africa by 2006 had become a less flexible labour market - an outcome that appears to be driven by the legislative provisions in hiring and firing. The legal analysis below appears to support this finding, given the emphasis on dismissal law within the legislative architecture. It should also be stated that South Africa's altered position in these international distributions will also of course be a function of the individual country experiences with their regulatory regimes. Ultimately, however, it remains true that the South African labour market, in an international context, it appears to have become more regulated over the last decade. 
Despite the above evidence, however, there remain three important caveats, which allude to the limitations of the approach and furthermore caution against treating these results as the only required evidence in measuring labour market regulation. In addition some, if not all of these caveats are, to varying degrees expanded in the sections below. Firstly, while many of the above sub-indices measure legislative provisions, they do not measure the interpretation of this legislation by the relevant courts of law. For example, in South Africa, the notion of a 'fair dismissal' lies at the heart of the dismissal provisions in the Labour Relations Act. In turn, close inspection of case law on this issue has indicated changing opinions and views of the Labour Court judges in the interpretation of this piece of legislation (see Thompson 1999; Cheadle et al 2005; Todd \& Damant 2004; Du Toit 2005). Indeed, one may find that the outcomes of the cases, if thoroughly investigated, indicate a measure of firing rigidity that may be less rigid than the formal legislative provisions may suggest. The second key caveat, relates to the issue of institutional capabilities and efficiency. It is entirely possible that neutral legislation may be rendered rigid through a malfunctioning institutional infrastructure. Hence, in the South African context it can be argued that its formal dispute resolution system, the Commission for Conciliation, Mediation and Arbitration (CCMA $)^{12}$, through its institutional weakness, discussed in more detail in the legal analysis, in fact results in enhancing the rigidity already present in the legislative provisions for dismissals. In addition, as we argue in that analysis, the Labour Courts remain inefficient and under-staffed, so possibly contributing to greater rigidity in the regulatory environment. Finally, the nature of the labour relations environment, specifically measured by the strength of employer and employee organisations can often shape the nature and extent of labour regulation, almost independent of the regulatory environment. While this measure was captured in the 1997 data above, it is not measured for the CDBS. Hence, while weak trade unions, for example, will not be able to ameliorate some of the unintended consequences of legislative provisions for workers, strong trade unions in turn will be swift in ensuring that the maximum benefit arising out of these provisions, do accrue to their members. Both environments, however, remain critical to how labour regulation and worker protection within an economy is measured and understood.

12 The CCMA was established by the 1995 LRA. The bulk of its work is to conciliate and arbitrate unfair dismissal disputes. But not all unfair dismissal disputes are conciliated or arbitrated by the CCMA. The LRA permits private conciliation and arbitration. The LRA also requires sectoral bargaining councils to conciliate and arbitrate disputes within their jurisdiction. It also reserves certain unfair dismissal disputes for determination by the Labour Court - primarily automatically unfair dismissals and operational requirement dismissals. 
This analysis, however, has operated at a level of generality which is, in most instances, inadequate for policy reform. More specifically, the approach has tended to ignore both the design of the labour regulatory environment in South Africa, and furthermore, what in particular may be required to tweak and alter such a design. It is to this, which the following sections turn. 


\section{Legal analysis}

\subsection{Approach to regulatory reform}

Reform is a loaded concept. For those who press for a deregulated labour market, reform means deregulation. We believe, however, that the proper approach ought to be directed to appropriate regulation, which may in any given case either amount to repeal or modification of existing regulation or the introduction of new regulation. We accept that there is a legitimate debate over the appropriateness of regulation but we believe that that it should neither be a blind adherence to deregulation or knee jerk refusal to consider any change to regulation. So, for us, appropriate regulatory reform may indeed mean the repeal of unnecessary or counterproductive regulation; just as it may require new forms of regulation, and, on occasion, more intensive forms. The approach should be to identify in a more nuanced way the sources of rigidity and cost. So for example we will argue that part of the transactional costs of dismissal is the costs associated with hearings and delays. Those costs can be significantly lowered if the dispute resolution institutions gear their jurisprudence and conduct, as was intended, towards speedy and informal dispute resolution. This approach won't mean that South Africa's rating will change but if adopted will go a long way to making the labour market less rigid in the sense that the transactional costs for engagement in the labour market are reduced.

It is also necessary to commence any discussion of labour market reform with a brief reminder that South Africa is a constitutional state with public international law obligations. Any discussion of legislative reform must accordingly take place in the context of the Constitution $^{13}$ and binding international law. ${ }^{14}$ So, for example, although the WBCDB criteria rate the prohibition of 'illegal' dismissal as a rigidity, the repeal of the legislative protections against unfair dismissal will prove to be unconstitutional. So, for example, although the right to unionise may contribute to South Africa's high score in respect of labour union power in Botero et al (See Figure 3) ${ }^{15}$, the legislature's power to suppress freedom of association is circumscribed by the constitutional protection of the right to organise and South Africa's

13 Particularly Section 24 of the Constitution that entrenches rights to fair labour practices, freedom of association, collective bargaining and strikes.

14 Particularly, the ratified ILO Conventions on freedom of association, collective bargaining (Conventions No 87 (1948) \& No 98 (1949))

15 We say 'may' contribute because the unions organising the majority black workforce became powerful with little legislative support in the 1970s and 1980s. It is important to note that the extent of trade union power (as elsewhere) is not simply the consequence of a legislative framework. It is a misnomer to characterise a regulatory framework that permits and promotes freedom of association as demonstrative of the extent of labour power in an economy. 
international law obligations flowing from its membership of the International Labour Organisation and its ratification of Conventions 87 on Freedom of Association and 98 on Collective Bargaining ${ }^{16}$.

The public international law obligations in respect of freedom of association and collective bargaining raise serious issues for the both the Botero and WBCDB studies. Firstly, all member states of the ILO have an obligation, arising from the very fact of membership, to respect, to promote and to realize, in good faith and in accordance with the ILO Constitution, the fundamental rights contained in the eight core ILO Conventions, which include Conventions 87 and $98 .{ }^{17}$ Secondly most countries in the world have ratified the conventions. ${ }^{18}$ Thirdly, those conventions have been underwritten by other international law instruments such as the International Covenant on Civil and Political Rights, the International Covenant on Social and Political Rights, the Universal Declaration of Human Rights. ${ }^{19}$ It follows that since most countries are required to respect, promote and realize these rights in their domestic legislation, it is invidious to measure their compliance with those obligations negatively. The impact of the regulatory framework for collective labour relations ought accordingly to be assessed in accordance with international law and not as subversive of it.

\subsection{Background to Dismissal Law}

It is important to understand the background to dismissal law in South Africa. Although there has been some protection against victimisation of trade union members since $1924,{ }^{20}$ dismissal disputes were regarded by the law as a species of interest disputes in respect of which employees could strike (and employers could lock out). ${ }^{21}$ In 1978 the Commission of Inquiry into Labour Relations, popularly known as the 'Wiehahn Commission' after its chairperson, recommended the abolition of job reservation for White workers but, in order to protect them from 'irregular actions' and dismissal for 'all kinds of petty and unjustifiable reasons'

16150 countries have ratified Convention 87 and 160 Convention 98 . The significant economies that have not ratified the Conventions are the United States, People's Republic of China and India. In both the US and India, there are legislative frameworks permitting and regulating freedom of association and collective bargaining.

17 ILO Declaration of Fundamental Principles and Rights at Work. See also L Swepston 'International Labour Law' in R Blanpain (ed) Comparative Labour Law and Industrial Relations in Industrialized Market Economies, Kluwer Law International at 145.

18150 member states have ratified Convention 87 and 160 Convention 98. Many of those countries that have not ratified the Conventions have domestic laws, including constitutional guarantees, recognising the freedom of association and collective bargaining.

19 Articles 22(1) of the ICCPR; 8(1) of the ICESCR; and 20(1) of the UDHR.

20 Act 11 of the Industrial Conciliation Act, 1924 and Act 27 of the Wage Act, 1925.

21 The definitions of 'strike' and 'lock out' in Section 1 of the Industrial Conciliation Act, 1924 included the employment or dismissal of an employee as one of the permissible purposes of a strike or a lock out. 
by 'unscrupulous employers' wanting to replace them with Black workers, the Commission recommended the introduction of a remedy for unfair labour practices as a necessary protective mechanism for White workers. ${ }^{22}$ The Labour Relations Amendment Act, 1979 gave effect to that recommendation by granting a remedy against unfair labour practices and conferring that jurisdiction on the Industrial Court. ${ }^{23}$ The scope of the remedy was wide and it did not take long for the unions organising African workers, who were at the brunt of arbitrary dismissal, to forge an unfair dismissal jurisprudence based on ILO Recommendation 116 on Termination of Employment. ${ }^{24}$ By the time that the constitutional negotiations began in 1992 , the courts had developed an extensive jurisprudence on unfair dismissal. And it was precisely this jurisprudence that the apartheid-era civil service wanted entrenched in the interim and final constitutions to protect itself from termination at the hands of a new Black government - a government that they feared would be retributive. This is the source of the inclusion of the right to fair labour practices in the interim constitution ${ }^{25}$, the constitutional principles ${ }^{26}$ and the final constitution. $^{27}$

\subsection{Outline of South Africa's Law of Dismissal}

Under the common law of employment, a contract of employment may be formed for a fixed period $^{28}$ or an indefinite one. This means that employers and employees are free to enter into any form of employment contract - it can be for a fixed term, which may range from a few hours to years or it can be indefinite until terminated on notice. Fixed term contracts terminate automatically on expiry unless the parties agree otherwise. Indefinite contracts terminate on notice..$^{29}$ Both contracts may be terminated summarily on grounds of material breach. This means that the reason for dismissal at common law is only relevant in the context of a

22 See A. Van Niekerk 'In Search of Justification: The Origins of the Statutory Protection of Security of Employment in South Africa' (2004) 25 Industrial Law Journal 853.

23 The Industrial Court was established in 1979 with the principal jurisdiction over unfair labour practices. It was replaced with the CCMA and the Labour Courts in 1995.

24 The core recommendation was the requirement that an employer dismiss only for a fair reason and after a fair procedure.

25 Section 27(1) of the Interim Constitution, 'Every person shall have the right to fair labor practices', 1994

26 Constitutional Principle XXVIII of Schedule 4 to the Interim Constitution: 'Notwithstanding the provisions of Principle XII, the right of employers and employees to join and form employer organisations and trade unions and to engage in collective bargaining shall be recognised and protected. Provision shall be made that every person shall have the right to fair labour practices.."

27 Section 23(1) of Constitution: 'Everyone has the right to fair labour practices'.

28 The fixed period may be determined by time or by the occurrence of an event. There are no common law restrictions on the period. It may be for a day or a weekend, which is how casual employees in the retail sector are employed, or it may be for a number of years, which is how professional employees working on construction projects are employed. 
premature termination - before the expiry of the fixed term contract or without notice. In all other instances, the contract can be terminated, at common law, for good reason, a bad one ${ }^{30}$ or no reason at all.

Section 185 of the LRA gives legislative form to the constitutional right to fair labour practices $^{31}$ : 'Every worker has the right not to be unfairly dismissed'. ${ }^{32}$ Section 187 lists the automatically unfair reasons for dismissal. ${ }^{33}$ Any other dismissal is unfair if the employer fails to prove that the reason for dismissal is a fair reason related to the employee's conduct or capacity; or based on the employer's operational requirements, and that the dismissal was effected in accordance with a fair procedure. ${ }^{34}$ The requirements for a fair reason and a fair procedure $^{35}$ are elaborated in codes of good practice ${ }^{36}$, which must be taken into account by employers when effecting a dismissal and arbitrators and judges when determining an unfair dismissal dispute. ${ }^{37}$ The object of the codes is to provide a set of established norms that may be departed from if justified by the circumstances. Reinstatement is the primary remedy. ${ }^{38}$ Compensation for unfair dismissal is capped. ${ }^{39}$

30 Of course, if the reason was not constitutionally permissible or against public policy, the common law would be developed to prohibit that kind of dismissal, as the courts have done in the US. But because these kinds of dismissal are already protected under the fair dismissal provisions of the LRA, there has been no need to develop common law remedies. In NEHAWU v University of Cape Town and others 2003 (2) BCLR 154 (CC), the Constitutional Court held that the right not to be unfairly dismissed is a core right protected under the right to fair labour practices.

32 Dismissal is defined as the termination by the employer but it includes other forms of termination such as constructive dismissal (resignation in circumstances where employer conduct makes continued employment intolerable) and the failure to renew a fixed term contract in circumstances where there was a reasonable expectation of renewal - Section 186 of the LRA. Section 187 of the LRA. These grounds include dismissal for: striking, refusing to do a strikers job, refusing to agree to changes to terms and conditions, exercising a right or participating in proceedings under the LRA, pregnancy, unfair discrimination, relating to a transfer of a business, and making protected disclosures.

35 The procedure for a fair dismissal based on operational requirements is not left to a code of good practice. The procedure or these collective dismissals are set out in section 189 of the LRA.

36 Code of Good Practice: Dismissal in Schedule 8 of the LRA and the Code of Good Practice on Dismissal Based on Operational Requirements published in the Government Gazette in GN 1517 in GG 20254 of 16 July 1999.

37 Section 203(3) of the LRA: 'Any person interpreting or applying this Act must take into account any relevant code of good practice'.

38 An arbitrator or judge does not need to reinstate or re-employ if: (a) the employee does not wish to be reinstated; (b) continued employment would be intolerable; (c) it is not reasonably practicable to reinstate; or (d) the dismissal is unfair only because the employer did not follow a fair procedure.

39 The cap is one year's remuneration unless the dismissal is held to be automatically unfair in which case the cap is two years Sections 193 \& 194 of the LRA. 


\subsection{Institutional landscape}

The Labour Relations Act established the Commission for the Conciliation, Mediation and Arbitration (the CCCMA). One of its functions (and its principal source of work) is to conciliate and arbitrate disputes arising from the fairness of a dismissal. ${ }^{40}$ It is not the only body charged with this function. Bargaining councils ${ }^{41}$ (collective bargaining institutions voluntarily established under the LRA at a sectoral level) are required to perform the same functions within their respective sectors. The Labour Courts, also established under the 1995 LRA, have original jurisdiction in respect of certain dismissals ${ }^{42}$ but only a review jurisdiction in respect of dismissals determined by arbitration. These jurisdictions are exclusive to the Labour Courts. The Labour Appeal Court, also established by the 1995 LRA, hears appeals from the Labour Court. This Court was intended to be the final court of appeal (except in constitutional matters) in respect of all disputes arising from the application and interpretation of the LRA, particularly unfair dismissal disputes. But the Supreme Court of Appeal ${ }^{43}$ has held that the 1996 Constitution gives it the jurisdiction to hear appeals from the Labour Appeal Court notwithstanding provisions to the contrary in the LRA. ${ }^{44}$

The procedures for the determination of unfair dismissal disputes involved a two-part process. All dismissal disputes must be referred to conciliation before being determined by arbitration or adjudication. If the dispute falls within the jurisdiction of a bargaining council, the council must conciliate the dispute. If not, the dispute must be conciliated by the CCMA. If the dispute is not settled at conciliation, the dispute must be determined by arbitration or adjudication depending on the nature of the dispute. ${ }^{45}$

$40 \quad$ All dismissal disputes must be conciliated but not all of them are required to be referred to arbitration. The kinds of dismissal listed in the next footnote fall within the jurisdiction of the Labour Courts.

41 A bargaining council is a registered collective bargaining institution for an economic sector and area. The parties to bargaining councils are employer associations and trade unions. For example, there is a bargaining council for the textile industry in which the employer association is representative of textile employers and the trade union is representative of textile workers. Collective agreements reached by these councils may be extended to non-party employers and employees in the industry for which the Council is registered.

42 They are: strike dismissals, operational requirement dismissals and discrimination dismissals.

43 The Supreme Court of Appeal is the most final court of appeal except in respect of constitutional matters.

$44 \quad$ NUMSA v Fry's Metals (Pty) Ltd (2005) 26 ILJ 689 (SCA)

45 Strike, discrimination and operational requirement dismissals must be determined by the Labour Court. All other dismissal disputes are determined by arbitration - either under the CCCMA or a bargaining council with jurisdiction. 
A careful analysis of the legal criteria used by the two studies that form the subject matter of this article reveals that an economy with less interference with the common law rules of contract and delict, the better its rating will be on the flexibility index. ${ }^{46}$ Given the public international law and constitutional obligations on the South African State, the removal of all the legislative protections is not legally possible. ${ }^{47}$ Accordingly, the LRA's starting point is those public international law and constitutional obligations. Section 23(1) guarantees the right to fair labour practices and the Constitutional Court has held that a core component of the right is the right not to be unfairly dismissed. The LRA gives effect to this right and the content of the right was drawn from ILO Convention 158 on Termination of Employment even though South Africa has not ratified the Convention. There are good reasons for adopting this course of action. Firstly, international law is an important source for interpreting constitutional rights. ${ }^{48}$ Secondly, the international labour standards are developed with the direct involvement of employer and worker representatives. Thirdly, the international standards on termination of employment had influenced the unfair labour practice jurisprudence under the old LRA.

But the Minister of Labour who initiated the new LRA was acutely aware of the transactional costs that the jurisprudence developed by the courts since 1979 had imposed on both employers and workers. That jurisprudence developed very strict requirements for predismissal procedures resulting in over-proceduralisation of pre-dismissal hearings and duplication when the dispute was again ventilated in the industrial court. However, it was not only the pre-dismissal procedures that imposed burdens. The development of the jurisprudence was on a case-by-case basis and it was often necessary to litigate to determine the fairness standard against which the employer's decision was to be assessed. The procedures in the industrial court, itself, were based on generic court procedures leading to extensive pre-trial steps, lengthy trials, legal costs and delays. Dismissal was also a significant cause of strikes prior to the introduction of the new LRA.

46 See, for example, the variables described in Botero et al for alternative employment contracts in the Appendix. Each of the variables is premised on contractual freedom and the weighting is triggered by measures that interfere with that freedom such as whether there are limitations on the freedom to enter into fixed term contracts. to guarantee freedom of association (see the criteria for labour union power in Appendix 1A), denunciation of ILO Conventions to release South Africa from the public law obligations concerning freedom of association and collective bargaining and the repeal of Section 23 of the Constitution. It may not be possible to repeal section 23 because the Constitutional Principles on which the final constitution had to be certified requires the inclusion of labour rights including the right to fair labour practices. 
The new LRA sought to introduce the following as measures to limit the transactional costs associated with unfair dismissal regulation:

There was to be a Code of Good Practice that was to be updated on a regular basis in order to keep the Code up to date with the jurisprudence developed by the Labour Courts. This was done to set the standards against which decisions ought to be assessed without being rigid - the norms contained in the Code could be departed from if the circumstances justified it. One of the circumstances listed is the size of the employer. It was also introduced in order to limit the parties' reliance on consultants and lawyers by providing an accessible code that the arbitrators and the courts were obliged to use.

Pre-dismissal procedures were to be brief but fair. As the Explanatory Memorandum that accompanied the Bill points out, the duplication, delays, costs and disproportionate impact on small employers who 'are often not able to follow elaborate pre-dismissal procedures' require a different approach to these procedures. The new norm was introduced into the Code of Good Practice, the important elements of which are that a pre-dismissal procedure 'does not need to be a formal enquiry' and that the employer 'should notify the employee of the allegations using a form and language that the employee can reasonably understand' and that the 'employee should be allowed the opportunity to state a case in response to the allegations'.

There was a high premium placed on the conciliation of dismissal disputes in order to limit the recourse to, or the costs of, adjudication and arbitration - the more costly of the processes. It was the expectation that if the dispute was settled, the transaction costs would be dramatically reduced. If the dispute as a whole was not settled, the conciliation was expected to yield an agreement on precisely what was to be referred to arbitration or adjudication.

The process known as con-arb was to be the principal process for the determination of unfair dismissal disputes. The process involves a single conciliator/arbitrator who first tries to conciliate the dispute and if the conciliation fails, there and then conducts an arbitration on the dispute. It is a process successfully used all over the world. It reduces costs for all parties, it improves the likelihood of realistic settlements in conciliation and it is demonstrably more expeditious.

It was the drafters' intention that the CCMA, the bargaining councils and the Labour Courts determine labour disputes expeditiously, particularly unfair dismissal disputes. To that end, they looked to a limited number of pre-trial steps with conciliation performing the 
most important step in pre-trial determination of dismissal disputes, namely the clarification of the issues for determination by arbitration or adjudication. Also to this end, the tripartite participation in the development of the Code of Good Practice provided a cheaper alternative to the employment of employer and employee assessors so critical to the legitimacy in the resolution of labour disputes.

Like elsewhere in the world, there were to be specialist courts established to determine labour disputes exclusively. The objects of a specialist court are to respond to the specific needs of a particular area of regulation. For labour market regulation, there is a premium on expertise, legitimacy and expedition. Expedition demands not only speedy processing to get to court, but also a limit on appeals to higher courts. Arbitration awards were meant to be final with the Labour Courts performing a limited supervisory role. Appeals were limited to one further tier the Labour Appeal Court. Apart from constitutional matters, the expressed intention of the LRA was to make the LAC the final court of appeal.

The parties to a dismissal dispute should be permitted to contract out of the statutory system by providing alternative processes to determine a dismissal dispute either by way of a collective agreement under the LRA or an arbitration agreement under the Arbitration Act. ${ }^{49}$

\subsection{Implementation of the Design}

Certain of the elements of the design have been effectively implemented - some have not - while other elements have been undermined by changes in the constitutional context and decisions of the arbitrators and the courts. The overall effect is that the transactional costs of unfair dismissal are higher than they need be to meet the constitutional protections of fairness. Each of the above elements will be separately dealt with in order to identify the reforms that ought to be introduced in order to cut the unnecessary costs for all parties in resolving unfair dismissal disputes.

\subsection{Code of Good Practice}

There are certain measures concerning the Code of Good Practice that have not been properly implemented. It was always the intention that the Code would embody the jurisprudence developed by the CCMA and the Labour Courts. Although the Code of Good Practice has been supplemented by a Code on Operational Requirement Dismissals in 1999

$49 \quad$ Act 42 of 1965 
and amended in 2002 to introduce changes in respect of probationary employees, the Code has not been kept up to date. It has, as a result, been an 'insufficient guide' ${ }^{50}$ to decision makers.

It is also evident from Benjamin (2006) that only 25 per cent of commissioners refer to the Code in their arbitration awards..$^{51}$ Section 203(3) of the LRA imposes a statutory duty on 'any person interpreting or applying' the Act to take the relevant code into account. The object of ensuring consistency and accordingly predictability, continues to be undermined by the failure to do so.

It is also evident from Van Niekerk (2007) that the failure to take the Code into account means that the arbitrators approach the question of fairness without a guiding norm or without a justification for departing from it. This is no more clearly illustrated by the CCMA and the Labour Courts jurisprudence on procedural fairness -'Commissioners have ignored the Code of Good Practice and continue to apply rigid rules of procedure, making punitive awards of compensation for even relatively minor lapses....'

The failure to take the Code into account has also had the effect that jurisprudence on the circumstances that may justify a departure from the Code has not been developed. Take probation for example, the CCMA failed to shape the norms of fairness in a context where new employees are being tested for the purpose of determining whether they are suitable for long term employment. The same can be said of the failure to develop a jurisprudence that took into account the special requirements of small business. 


\subsection{Pre-Dismissal Procedures}

Although there are a few decisions ${ }^{52}$ that chart the route intended by the Code in respect of pre-dismissal procedures, the CCMA and Labour Court jurisprudence has continued to impose the rigid and formalistic approach adopted by the courts under the old LRA ${ }^{53}$ by overemphasising pre-dismissal procedures and in so doing imposing an unnecessary burden on employers without advancing the protection of workers.

There are various reasons for this. Firstly, the Industrial Court had developed a jurisprudence under the old LRA that imposed strict procedural requirements on pre-dismissal hearings and despite the endeavour in the new LRA to break from this approach, lawyers, arbitrators and judges, schooled under the old LRA, continued to apply the technical and exacting jurisprudence in developing the new. Secondly, employers had established complex disciplinary procedures under the old LRA but did not alter those procedures with the introduction of the 1995 Act. Thirdly, faced with the arbitrators' and judges' decisions continuing the old jurisprudence, lawyers and consultants gave advice that protected the interests of their clients, which happily happened to coincide with their own. Finally, the model of disciplinary hearings developed under the 1956 Act, premised as it was on an analogy with criminal proceedings, did not die and give way to the model advanced under the 1995 Act, which is more analogous to procedures under administrative law that are more flexible and based on the Code of Good Practice.

Until the courts and arbitrators change their approach to procedural fairness, employers will continue to engage in costly formal hearings or pay dearly for not doing so. Recent research demonstrates that over three quarters of cases, in which findings are made against employers, involve findings of pre-dismissal procedural unfairness. ${ }^{54}$ The high prevalence of these findings point to a too fastidious approach given the very limited requirements for procedural fairness in the Code. ${ }^{55}$

\footnotetext{
52 Avril Elizabeth Homes for the Mentally Handicapped v CCMA and Others [2006] 9 BLLR 833 (LC)

53 Probably the most important case establishing this jurisprudence is Mahlangu/CIM Deltak, Gallant v CIM Deltak (1986) 7 ILJ 346 (IC).

54 Benjamin (2006)

55 But as Benjamin (2006) points out, there is a high percentage of cases in which the employer, normally small, who conduct no hearing at all, pointing to a lack of knowledge of the law and its minimal requirements.
} 
Both Van Niekerk (2006) and Roskam (2006) regard the requirements for pre-dismissal procedural fairness imposed by the arbitrators and the courts as having 'contributed more than any other factor to perceptions about the inflexibility of South African labour law'.

\subsection{Probationary Employees}

Probation is a vexed issue. Employers need it in order to assess the suitability of the employee in the work situation. If an employer is unable to dismiss an employee that proves to be unsuitable with relative ease during probation, the purpose of probation is undermined and may become a barrier to employment. On the other hand, there is the concern that unscrupulous employers will use the reduced level of protection during probation to dismiss employees at the end of the probationary period and to replace them with new employees.

Nothing was initially said about probation in the Code of Good Practice: Dismissal except the general injunction that the Code was 'intentionally general' and that 'departures from the norm may be justified in proper circumstances'. Probation is just such a circumstance and the CCMA should have developed less stringent standards for the fair termination of a probationary employee, but it did not. For this reason the Code was amended in 1998 requiring the probationary period to be of reasonable duration and requiring the employer to provide appropriate training, instruction, and an opportunity to improve. But no coherent set of guidelines based on the revised Code was developed and the arbitrators continued to treat probationary employees no differently from employees accepted into long term employment. In 2002, the Code of Good Practice was again amended. The amendment introduced a requirement that appeared to lower the threshold for substantive fairness in respect of performance related dismissals but included a regulatory thicket of evaluation, instruction, training, guidance and counselling. Part of that package was to make unfair conduct (but not dismissal) relating to probation an unfair labour practice by including it in the definition of unfair labour practice.

There are several difficulties with the approach adopted in the amendments to the Code and the LRA. The first is that the less compelling standard for assessing the fairness of the dismissal of a probationary employee applies only to performance. ${ }^{56}$ But probation is also about testing the employee's suitability in the workplace, which is a more difficult discretion to effectively review. This is why the lower standard is restricted to performance - an example

$56 \quad$ Item 8(1)(j) of the Code. 
of a policy driven by concerns related to the efficacy of enforcement rather than the efficacy of the selection process. The trade-off arises because the wrong regulatory mechanism is chosen.

The second problem is the inclusion of unfair conduct relating to probation (other than dismissal) as an unfair labour practice. ${ }^{57}$ The amendment was driven by the fear that the introduction of a less stringent standard would lead employers to repeatedly extend the probationary period. It is hard to conceive of any other reason that would justify extending judicial oversight to probation. If that is correct, there is much easier and more efficacious way to address the problem.

The third problem is that this whole construct of regulation is easily avoided. The employer simply eschews a probationary period of employment and simply enters into a fixed term contract of a few weeks or months to determine whether the employee is suitable. If the employee is not suitable, the contract terminates automatically at the end of the period. If the employee is suitable, the employer engages the employee in indefinite employment.

\subsection{Functioning of the CCMA and the Labour Courts}

Approximately 80000 to 90000 dismissal cases are referred to the CCMA each year amounting to 80 per cent of its referrals. ${ }^{58}$ The number that culminate in arbitration awards amount to roughly 11000 per annum. ${ }^{59}$ The high number of referrals for conciliation demonstrates the legitimacy of the institution and the high number of referrals settled through conciliation demonstrates that, despite criticism of the manner in which settlements are sometimes leveraged, the institution has played an important role in reducing the number of disputes going into the more expensive process of arbitration. But the high number of referrals has led to proposals for disincentives and exclusions, proposals for law reform which will be considered in more detail below.

\footnotetext{
$57 \quad$ Section 186(1)(a) of the LRA.

58 Benjamin (2006).

59 Benjamin (2006). This figure excludes those arbitrations which culminate in a default award because the employer fails to attend or in which the case is dismissed because of non-appearance of the applicant employee.
} 
Van Niekerk (2006) records that it often takes between 12 to18 months from the date of referral for a matter to be heard in the Labour Court. In the Labour Appeal Court it is reported that delays of 12 to 18 months between date of hearing and date of judgment are not uncommon. Although the uncertainty concerning the restructuring of the Labour Courts has had an effect on the efficacy of the Labour Courts, these delays run counter to one of the reasons for a specialist labour court namely expedition. If the Supreme Court of Appeal can on average hand down judgments within three months of the hearing, there is no reason why the Labour Appeal Court cannot do the same.

\subsection{Dispute Resolution by Bargaining Councils and Private Agencies}

One of the goals of the dispute resolution system was to require bargaining councils to resolve disputes between their parties and to ensure the quality of dispute resolution in so far as nonparties are concerned through a system of accreditation and subsidy. ${ }^{60}$ In 2004, over 2.3 million employees fell within the jurisdiction of bargaining councils of which 34 were accredited for the conciliation and arbitration of disputes and 16 for conciliation only. ${ }^{61}$ About 35000 disputes ${ }^{62}$ were referred to bargaining councils in 2003/4 - approximately 27 per cent of those referred to the CCMA in the same year. ${ }^{63}$ But the settlement rate is low - only 22 per cent of the disputes referred are settled ${ }^{64}$, significantly less than the settlement rate of the CCMA.

The LRA also sought to encourage the establishment of private agencies to both relieve the pressure on the CCMA, to assist bargaining councils in meeting their statutory obligations and to allow employers and trade unions to develop dispute resolution systems tailored to their needs. The LRA did this by providing for the accreditation and subsidisation of private agencies by the CCMA. ${ }^{65}$ Notwithstanding several applications to be accredited several years ago, the CCMA Governing Body has failed to accredit a single private agency.

\footnotetext{
60 See Chapter VII Part B of the LRA.

61 See www.ccma.org.za

62 Including both party and non-party disputes but excluding disputes concerning the application and interpretation of collective agreements.

63 Bosch et al, The Conciliation and Arbitration Handbook (2004) at 45 and 176.

64 Department of Labour, Preliminary Annual Report 2001/2002 (2002) 33: www.labour.gov.za.

65 See Chapter VII Part B.
} 


\subsection{Weaknesses in the Design}

If there have been failures in the implementation of the new design there have also been weaknesses in the design itself. These weaknesses have become apparent over the last ten years.

\subsection{Application of Dismissal Protection to Senior Management and Professional Employees}

The unfair dismissal protections in the LRA apply to all employees. There is no compelling reason for extending unfair dismissal protection to senior management and professional employees, other than on grounds of discrimination, victimisation or association. They are normally able to protect themselves contractually. Moreover, from a policy perspective, interference with termination decisions in respect of these kinds of employees is more invasive with greater consequences for the efficiency of the enterprise. Although the issue had been considered in the drafting of the new LRA, the exclusion was not effected for two reasons: (a) the drafters took the view that senior management and professional employees would look to contractual remedies rather than the capped compensation under the statute; and (b) the exclusion raised the constitutional issues. Because the unfair dismissal remedies are in addition to any contractual remedies, these employees were able to leverage the one year compensation cap as part of the settlement package. The constitutional issues are also not insurmountable. The Bill of Rights contemplates justifiable limitations of constitutional rights ${ }^{66}$ and for the reasons outlined above and because ILO Convention 158 contemplates the limited exclusion this category of employee ${ }^{67}$, the exclusion of senior management and professional employees from dismissal protection should pass constitutional muster.

66 Section 36 of the Constitution, 1996: 'The rights in the Bill of Rights may be limited only in terms of law of general application to the extent that the limitation is reasonable and justifiable in an open and democratic society based on human dignity, equality and freedom, taking into account all relevant factors, including :

a) the nature of the right;

b) the importance of the purpose of the limitation;

c) the nature and extent of the limitation;

d) the relation between the limitation and its purpose; and

e) less restrictive means to achieve the purpose.

2) Except as provided in subsection (1) or in any other provision of the Constitution, no law may limit any right entrenched in the Bill of Rights.

67 Clause 5 of the Convention permits member states to exclude 'limited categories of employed persons in respect of which special problems of a substantial nature arise in the light of the particular conditions of employment of the workers'. See also paragraphs 66-68 of the Committee of Experts, 1995 General Survey on Protection Against Unjustified Dismissal, International Labour Office, Geneva. 


\subsection{Application of Statutory Retrenchment Procedures to Small Businesses}

Unlike the Code of Good Practice: Dismissal, which provides guidelines for a fair predismissal procedure in respect of misconduct and incapacity dismissals, section 189 of the LRA prescribes a procedure for operational requirement dismissals. That procedure requires prior notification, consultations, consideration of alternatives, selection criteria, re-employment commitments etcetera. It is designed with the medium to large employer in mind. But, because the procedure is contained in the statute, it is not a guideline and employers must apply the procedure regardless of the circumstances. It is part of the argument developed later that it is not the exclusion of small business from the requirement of fairness that is the root of this particular problem, but the imposition of a statutory standard rather than a flexible guideline for fairness.

\subsection{Compensation for Procedural Unfairness}

Part of the problem associated with the formalistic approach to pre-dismissal procedures is that arbitrators have awarded compensation for procedural irregularities not contemplated in the Code's requirements for procedural fairness in misconduct and incapacity dismissals. Van Niekerk (2007) demonstrates in a study of awards over a four year period that there is significant inconsistency in the reasons for and the amount of compensation awarded by arbitrators. Given the Code's approach to procedural fairness, compensation ought not to be awarded for any procedural unfairness. The open discretion given to arbitrators and the lack of guidelines on compensation is one cause for this state of affairs. The LRA's approach to compensation ought to be aligned to the Code's approach to procedural fairness. 


\subsection{Appellate Structure in Dismissal Disputes}

Because the right not to be unfairly dismissed is a constitutionally protected right $^{68}$, the application and interpretation of laws giving effect to that right constitutes a constitutional matter over which the Constitutional Court has final jurisdiction. ${ }^{69}$ The effect of this decision is that there is necessarily an additional layer of appeal in dismissal disputes - not that the Constitutional Court will hear all appeals, it retains a discretion which it has used on a number of occasions to refuse to hear appeals from the Supreme Court of Appeals or the Labour Appeal Court.

Although it was constitutionally possible to have specialist appeal courts with equivalent status of the Supreme Court of Appeals under the interim Constitution - that no longer became possible under the 1996 Constitution - which explicitly provides that the Supreme Court of Appeals is the highest court of appeal except in constitutional matters. ${ }^{70}$ In a recent decision of the Supreme Court of Appeal, the Court held that it had jurisdiction to hear appeals from the Labour Appeal Court. ${ }^{71}$ This has introduced a further (and non-specialist) tier of appeals in labour disputes. As a result the structure envisaged in the LRA of having a Labour Appeal Court with same status as the Supreme Court of Appeal is no longer constitutionally possible. The latter requires a restructuring of the Labour Courts in order to preserve the original intention of limiting the levels of appeal in respect of labour disputes both because of the transactional costs but also because of the need to have expeditious determination of labour disputes in order to advance labour peace.

\subsection{Reforming the Labour Market: A Synthesis of Proposed Interventions}

The above analysis suggests a number of reforms to improve the functioning of the legislative and institutional design to both limit transactional costs and to modify the perceptions that the South African dismissal regime is inflexible. Provided below, is a deliberately brief synopsis of the interventions that would be required in order to deal with the regulatory issues noted above.

68 In NEHAWU v University of Cape Town, the Constitutional Court held that one of the core rights contained in the right to fair labour practices in section 23(1) of the Constitution is the right not to be unfairly dismissed.

$69 \quad$ NEHAWU at paragraph (15)

70 Section 168(3) of the Constitution.

71 National Union of Metalworkers of South Africa v Fry's Metals (Pty) Ltd (2005) 26 ILJ 689 (SCA) 


\subsection{Small Employers}

There should be a Code of Good Practice for Small Employers .It should provide appropriate guidelines on substantive and procedural fairness - guidelines crafted to take account of the personal nature of the employment relationship, the capacity and resources of the employer and the employee, and special circumstances such as the provision of accommodation. The statutory procedures for a fair dismissal for operational requirements should not apply to small employers. ${ }^{72}$ Although the dismissal for operational requirements should remain procedurally fair $^{73}$, the procedures appropriate to small employers should be contained in the Code.

\subsection{Probationary Employees}

The dismissal protection (other than dismissal for automatically unfair reasons ${ }^{74}$ ) contained in Chapter VIII of the LRA should not apply to probationary employees. The simplest way to give effect to this is to exclude all employees with less than six months experience ${ }^{75}$ and to provide safeguards against abuse. ${ }^{76}$

\subsection{Senior Management and Professional Employees}

The dismissal protection (other than dismissal for automatically unfair reasons) should not apply to senior management and professional employees. ${ }^{77}$

$72 \quad$ This amendment will require Section 189 to be amended to exclude small employers. This, in turn, will require a definition of a small employer. In Cheadle 2006, the suggestion is made that small business should be based on turnover and certified by South African Revenue Services. To include employers who are not businesses such as domestic employers, the definition should also have a numerical threshold. Note, though, that although Section 189 should not apply to small employers, they will nevertheless remain bound by Section 189 , which requires a fair procedure before an employee is dismissed.

73 For the reasons set out in Cheadle 2006, the exclusion of small employers and their employees from the scope of dismissal protection may trench on the constitutional right to fair labour practices.

74 Automatically unfair reasons are listed in section 187(1) and include dismissal for participating in a protected strike, for exercising a right conferred by the LRA, on grounds of pregnancy etc.

75 This should be supplemented with permitting collective agreements to set different thresholds and allowing the Minister to extend the qualifying period in circumstances where longer periods of probation are operationally required.

76 In order to prevent employers continually hiring the same employees on fixed term contracts short of six months each time, the statute should define the period of employment as including all previous employment with that employer.

77 Rather than seeking to define senior management and professional employees, employees above a monetary threshold determined by the Minister from time to time should be excluded from dismissal protection. What is contemplated is the kind of provision found in section 6(3) of the BCEA. 


\subsection{Code of Good Practice: Dismissal}

The Codes of Good Practice ${ }^{78}$ on dismissal need to be updated and merged. The update must be based on the emerging jurisprudence from the CCMA and the Courts and any legislative amendments that may flow from the current review of labour market regulation. ${ }^{79}$ The update should also spell out more clearly precisely what is required for pre-dismissal procedures. The Code should be directed primarily at employers, workers and their representatives. The CCMA should develop more detailed guidelines based on the Code to guide its commissioners and bargaining council conciliators and arbitrators.

In order to ensure that the Codes of Good Practice are properly considered and, when necessary applied, the grounds for reviewing a CCMA or Bargaining Council award on the fairness of a dismissal should include the failure to refer to, consider or apply, when necessary, an applicable Code of Good Practice. ${ }^{80}$

\subsection{Structure of the Courts}

In order to meet the requirements for the expeditious resolution of labour disputes, the specialist nature of labour law and the constitutional structure of courts ${ }^{81}$, it is necessary that the Labour Appeal Court be disestablished and that appeals go to the Supreme Court of Appeal. There are various ways to retain specialisation - one is the current proposal in the Superior Courts Bill ${ }^{82}$ to establish a specialist panel headed by a Deputy Judge President within the Supreme Court of Appeal. Another is to ensure that the appointments are made with an eye to ensure that there are sufficient labour law specialists on the Supreme Court of Appeal appropriately addresses the requirements of expedition, specialisation and constitutionality. Whatever mechanism is chosen, the current system in which the Judicial Service Commission consults with representatives of workers and employers before appointing labour judges should be retained.

\footnotetext{
78 Code of Good Practice: Dismissal and the Code of Good Practice: Dismissal for Operational Requirements

79 So for example, if the LRA is amended to introduce a qualifying period for application of unfair dismissal protection, that would require an amendment of the Code to remove the current provisions relating to probation.

80 This would require an amendment to section 145 of the LRA.

81 See NUMSA v Fry's Metals

82 Bill B52-2003: To consolidate and amend the laws relating to the Constitutional Court, the Supreme Court of Appeal and the High Court of South Africa; and to provide for matters incidental thereto.
} 


\subsection{Institutional Reforms within the CCMA}

The CCMA should develop more detailed guidelines based on the Code to guide its commissioners and bargaining council conciliators and arbitrators. The guidelines should address the factors that should be taken into account in determining procedural fairness, the approach to compensation for procedural fairness (that is, that compensation should only be granted if there is a flagrant breach of the Code) and the approach to interfering with the imposition of sanction.

The CCMA should include the use of the Code and the Guidelines as a measure of performance of Commissioners and make it a disciplinary offence for an arbitrator to fail to consider the Code or the CCMA Guidelines, to state in the award that they have been considered, to apply them or, if they are departed from, to state the reasons for doing so.

The CCMA should train Commissioners on the Code and its Guidelines and to offer training on the Code and its Guidelines to employers, trade unions and the legal profession. 


\section{Conclusion}

The paper has attempted to provide two distinct, yet inter-linked, analytical exercises on the labour regulatory environment facing South Africa. At the outset, the hope is that the paper has established that examining regulatory issues in the labour as a binary policy alternative - flexibility versus regulation - is conceptually and empirically wrong. Indeed, the approach of merging the thinking, concerns and approaches of legal experts with that of economists underlies this core message of the paper.

The empirical evidence attempting to position South Africa's labour regulatory regime within an international context yields three key results. Firstly, that in most measures of labour regulation for both the 1990s and the 2006 data, South Africa is not an extraordinarily over-regulated (or indeed under-regulated) labour market. This holds true for both the global samples and the sample of middle-income economies. This result reinforces the view taken in this paper, that labour market policy debates in South Africa should be about nuance, rather than substance. Secondly, on the basis of the 1997-2006 inter-temporal comparison there is evidence, within the global distribution of labour regulation, of an increase in hiring and firing rigidity, but a decline in hiring and firing costs. Finally, the legislative source of any increased actual or perceived rigidity in the South African labour market would, therefore, have to be - on the basis of this evidence - located around clauses and provision for the dismissal of workers.

Indeed, the second segment of the paper focuses disproportionately on the micro-reforms required in order to reduce unnecessary costs for all parties involved in unfair dismissal disputes. The evidence presented suggests that a package of legislative reforms could possibly be introduced in relation to issues such as pre-dismissal and con/arb procedures; codes of good practice including amending and in some cases simplifying these relevant codes; employers and employees rights during the probation period and so on. The second key set of recommendations revolve around improving the efficiency and effectiveness of the relevant labour market institutions. These include the CCMA, the Labour Courts and the Bargaining Councils and proposals ranging from training of commissioners to subsidising under-funded bargaining councils.

Given the centrality of the unemployment rate (together possibly with the skills shortage issue) to South Africa's long-term welfare challenge, attention within the policy environment has often turned to reforming the labour market. Having gone through one round of amendments, it appears that the economy may be heading for a second round. We have tried here to present 
evidence with this pending process in mind - with the explicit aim of achieving some positive success in the labour market reform packages that may emanate from these debates. 


\section{References}

\section{Laws}

Basic Conditions of Employment Act, 75 of 1997 (BCEA)

Constitution of the Republic Act, 200 of 1993 (Interim Constitution)

Constitution of the Republic Act, 108 of 1996 (Constitution)

Labour Relations Act, 66 of 1995 (LRA)

\section{$\underline{\text { Cases }}$}

Avril Elizabeth Homes for the Mentally Handicapped v CCMA and Others [2006] 9 BLLR 833 (LC)

Mahlangu v CIM Deltak, Gallant v CIM Deltak (1986) 7 ILJ 346 (IC).

NEHAWU v University of Cape Town and others 2003 (2) BCLR 154 (CC)

NUMSA v Fry's Metals (Pty) Ltd (2005) 26 ILJ 689 (SCA)

\section{Articles and Books}

Benjamin,P (2006) Beyond 'Lean' Social Democracy: Labour Law and the Challenge of Social Protection. Unpublished mimeo. School of Law: University of Cape Town: Cape Town.

Benjamin, P (2006) The Regulatory Efficiency of the CCMA: A Statistical Analysis of the CCMA's CMS Database Paul Benjamin and Carola Gruen Unpublished mimeo. School of Law: University of Cape Town: Cape Town. DPRU Working Paper No 06/110. Development Policy Research Unit: University of Cape Town. Cape Town.

Benjamin, P (2007) The Impact of the Decisions of the Labour Courts on the Operation of the CCMA. Unpublished mimeo. School of Law: University of Cape Town: Cape Town.

Bhorat,H (2006)Labour Supply and Demand Constraints on Employment Creation: A Microeconomic Analysis. In Vishnu Padayachee (ed), The Development Decade? Economic and Social Change in South Africa, 1994-2004. Cape Town: HSRC Press. Pp. 273-323 
Botero,J.C, S.Djankov, R. La Porta, F. Lopez-de-Silanes and A. Shleifer, (2004) The Regulation of Labour, Quarterly Journal of Economics. November. 1339-1382

Bosch, D, Molahlehi, E and Everett, W, The Conciliation and Arbitration Handbook (2004), pp. 45 and 176.

Cheadle, H., Thomson, C., Le Roux, P. K. \& Van Niekerk, A. (2005). Current labour law: the authoritative annual review of labour law. Durban: Lexis Nexis Butterworths.

Cheadle, H, 2006. Regulated Flexibility and Small Business: Revisiting the LRA and the BCEA. DPRU Working Paper No 06/109. Development Policy Research Unit: University of Cape Town. Cape Town.

Djankov, S, R. La Porta, F. Lopez-de-Silanes and A. Shleifer, (2002) The Regulation of Entry, Quarterly Journal of Economics, 117, 1-37.

Chandra,V et al (2000) Constraints to Growth and Employment in South Africa. Report 1: Statistics from the Large Manufacturing Survey, World Bank Discussion Paper 14, World Bank: Washington.

Cost of Doing Business Survey, 2006. http://www.doingbusiness.org/MethodologySurveys/Accesssed?

Devey, R. et. al. 2005. Constraints to Growth and Employment: Evidence from the Greater Durban Metropolitan Area. Research Report No 64. School of Development Studies, University of KwaZulu-Natal.

Djankov, S, R. La Porta, F. Lopez-de-Silanes and A. Shleifer, (2003) Courts, Quarterly Journal of Economics, May, 453-517.

Du Toit,D (2005) Business Restructuring and Operational Requirements Dismissals: Algorax and Beyond. Industrial Law Journal. 26. April.595-617.

Forteza, Alvaro and Martín Rama (2001), "Labor Market Rigidity and the Success of Economic Reforms across More than 100 Countries," mimeo. The World Bank: Washington DC

Godfrey, S \& J.Theron, 2004. An Analysis Of The Impact Of Legislation And Policy On The Labour Market Since 1994. University of Cape Town. Unpublished mimeo.

Heckman, James and Carmen Pagés,(2000) The Cost of Job Security Regulation: Evidence from Latin American Labor Markets, NBER Working Paper 7773 www.nber.org/papers/w7773

Heckman, J \& C.Pagés (2003) Law and Employment: Lessons from Latin America and the Caribbean. NBER Working Paper 10129. www.nber.org/papers/w10129 
Lazear,E Job Security Provisions and Employment (1990) Quarterly Journal of Economics. August. 699-726.

Nicoletti, G \& S.Scarpetta "Regulation, Productivity and Growth: OECD Evidence," Economic Policy 9-72, (2003).

OECD (2004) OECD Employment Outlook. Chapter 2: Employment protection Regulation and Labour Market Performance. OECD: Paris.

Rankin, N (2006) The Regulatory Environment and SMMEs. Evidence from South African Firm Level Data . DPRU Working Paper No. 06/113. Development Policy Research Unit: University of Cape Town.

Roskam, A (2007) An Exploratory Look Into Labour Market Regulation. DPRU Working Paper No.07/116. Development Policy Research Unit: University of Cape Town.

Swepston, L (2004) 'International Labour Law' in R Blanpain (ed) Comparative Labour Law and Industrial Relations in Industrialized Market Economies, Kluwer Law International at 145

Thompson,C (1999) Bargaining, Business Restructuring and the Operational Requirements Dismissal. 20. Industrial Law Journal. 755-769

Todd,C \& G.Damant (2004) Unfair Dismissal - Operational Requirements. Industrial Law Journal, 25. 896-922

Van Niekerk, A (2004) 'In Search of Justification: The Origins of the Statutory Protection of Security of Employment in South Africa' (2004) 25 Industrial Law Journal 853

Van Niekerk, A (2007) Regulating Flexibility and Small Business: Revisiting The LRA and BCEA - A Response To Halton Cheadle's Draft Concept Paper. DPRU Working Paper No. 07/119. Development Policy Research Unit: University of Cape Town. 


\section{Appendices}

\section{A1: Detailed Overview of Elements of Labour Regulation Index}

\begin{tabular}{|c|c|}
\hline Variable & Description \\
\hline \multicolumn{2}{|l|}{ Employment laws } \\
\hline $\begin{array}{l}\text { Alternative employment } \\
\text { contracts }\end{array}$ & $\begin{array}{l}\text { Measures the existence and cost of alternatives to the standard employment contract, } \\
\text { computed as the average of (1) a dummy variable equal to one if part-time workers enjoy } \\
\text { the mandatory benefits of full-time workers, (2) a dummy variable equal to one if terminating } \\
\text { part-time workers is at least as costly as terminating full-time workers, (3) a dummy variable } \\
\text { equal to one if fixed-term contracts are only allowed for fixed-term tasks, and (4) the normalized } \\
\text { maximum duration of fixed-term contracts. }\end{array}$ \\
\hline $\begin{array}{l}\text { Cost of increasing hours } \\
\text { worked }\end{array}$ & $\begin{array}{l}\text { Measures the cost of increasing the number of hours worked. We start by calculating the } \\
\text { maximum number of "normal" hours of work per year in each country (excluding overtime, } \\
\text { vacations, holidays, etc.). Normal hours range from } 1,758 \text { in Denmark to } 2,418 \text { in Kenya. } \\
\text { Then we assume that firms need to increase the hours worked by their employees from } 1,758 \\
\text { to } 2,418 \text { hours during one year. A firm first increases the number of hours worked until it } \\
\text { reaches the country's maximum normal hours of work, and then uses overtime. If existing } \\
\text { employees are not allowed to increase the hours worked to } 2,418 \text { hours in a year, perhaps } \\
\text { because overtime is capped, we assume that the firm doubles its workforce and each worker } \\
\text { is paid } 1,758 \text { hours, doubling the wage bill of the firm. The cost of increasing hours worked is } \\
\text { computed as the ratio of the final wage bill to the initial one. }\end{array}$ \\
\hline Cost of firing workers & $\begin{array}{l}\text { Measures the cost of firing } 20 \text { percent of the firm's workers ( } 10 \text { percent are fired for redundancy } \\
\text { and } 10 \text { percent without cause). The cost of firing a worker is calculated as the sum of the notice } \\
\text { period, severance pay, and any mandatory penalties established by law or mandatory collective } \\
\text { agreements for a worker with three years of tenure with the firm. If dismissal is illegal, we set } \\
\text { the cost of firing equal to the annual wage. The new wage bill incorporates the normal wage of } \\
\text { the remaining workers and the cost of firing workers. The cost of firing workers is computed as } \\
\text { the ratio of the new wage bill to the old one. }\end{array}$ \\
\hline
\end{tabular}




\begin{tabular}{|c|c|}
\hline Dismissal procedures & $\begin{array}{l}\text { Measures worker protection granted by law or mandatory collective agreements against } \\
\text { dismissal. It is the average of the following seven dummy variables which equal one: (1) if the } \\
\text { employer must notify a third party before dismissing more than one worker, (2) if the employer } \\
\text { needs the approval of a third party prior to dismissing more than one worker, (3) if the employer } \\
\text { must notify a third party before dismissing one redundant worker, (4) if the employer needs } \\
\text { the approval of a third party to dismiss one redundant worker, (5) if the employer must provide } \\
\text { relocation or retraining alternatives for redundant employees prior to dismissal, (6) if there } \\
\text { are priority rules applying to dismissal or layoffs, and }(7) \text { if there are priority rules applying to } \\
\text { reemployment. }\end{array}$ \\
\hline Employment laws index & $\begin{array}{l}\text { Measures the protection of labor and employment laws as the average of (1) Alternative } \\
\text { employment contracts, (2) Cost of increasing hours worked, (3) Cost of firing workers, and (4) } \\
\text { Dismissal procedures. }\end{array}$ \\
\hline \multicolumn{2}{|l|}{ Collective relations laws } \\
\hline Labor union power & $\begin{array}{l}\text { Measures the statutory protection and power of unions as the average of the following seven } \\
\text { dummy variables which equal one: (1) if employees have the right to unionize, (2) if employees } \\
\text { have the right to collective bargaining, (3) if employees have the legal duty to bargain with } \\
\text { unions, (4) if collective contracts are extended to third parties by law, (5) if the law allows closed } \\
\text { shops, (6) if workers, or unions, or both have a right to appoint members to the Boards of } \\
\text { Directors, and (7) if workers' councils are mandated by law. }\end{array}$ \\
\hline Collective disputes & $\begin{array}{l}\text { Measures the protection of workers during collective disputes as the average of the following } \\
\text { eight dummy variables which equal one: (1) if employer lockouts are illegal, (2) if workers have } \\
\text { the right to industrial action, (3) if wildcat, political, and sympathy/solidarity/secondary strikes } \\
\text { are legal, (4) if there is no mandatory waiting period or notification requirement before strikes } \\
\text { can occur, (5) if striking is legal even if there is a collective agreement in force, (6) if laws do } \\
\text { not mandate conciliation procedures before a strike, (7) if third-party arbitration during a labor } \\
\text { dispute is mandated by law, and (8) if it is illegal to fire or replace striking workers. }\end{array}$ \\
\hline $\begin{array}{l}\text { Collective relations laws } \\
\text { index }\end{array}$ & $\begin{array}{l}\text { Measures the protection of collective relations laws as the average of (1) Labor union power } \\
\text { and (2) Collective disputes. }\end{array}$ \\
\hline \multicolumn{2}{|l|}{ Social security laws } \\
\hline $\begin{array}{l}\text { Old-age, disability, and } \\
\text { death benefits }\end{array}$ & $\begin{array}{l}\text { Measures the level of old-age, disability, and death benefits as the average of the following four } \\
\text { normalized variables: (1) the difference between retirement age and life expectancy at birth, (2) } \\
\text { the number of months of contributions or employment required for normal retirement by law, } \\
\text { (3) the percentage of the worker's monthly salary deducted by law to cover old-age, disability, } \\
\text { and death benefits, and (4) the percentage of the net pre-retirement salary covered by the net } \\
\text { old-age cash-benefit pension. }\end{array}$ \\
\hline
\end{tabular}




\begin{tabular}{|l|l|}
\hline $\begin{array}{l}\text { Sickness and health } \\
\text { benefits }\end{array}$ & $\begin{array}{l}\text { Measures the level of sickness and health benefit as the average of the following four } \\
\text { normalized variables: (1) the number of months of contributions or employment required to } \\
\text { qualify for sickness benefits by law, (2) the percentage of the worker's monthly salary deducted } \\
\text { by law to cover sickness and health benefits, (3) the waiting period for sickness benefits, and } \\
\text { (4) the percentage of the net salary covered by the net sickness cash benefit for a two-month } \\
\text { sickness spell. }\end{array}$ \\
\hline Unemployment benefits & $\begin{array}{l}\text { Measures the level of unemployment benefits as the average of the following four normalized } \\
\text { variables: (1) the number of months of contributions or employment required to qualify for } \\
\text { unemployment benefits by law, (2) the percentage of the worker's monthly salary deducted } \\
\text { by law to cover unemployment benefits, (3) the waiting period for unemployment benefits, and } \\
\text { (4) the percentage of the net salary covered by the net unemployment benefits in case of a } \\
\text { one-year unemployment spell. }\end{array}$ \\
\hline Social security laws index & $\begin{array}{l}\text { Measures social security benefits as the average of (1) Old-age, disability, and death benefits, } \\
\text { (2) Sickness and health benefits, and (3) Unemployment benefits. }\end{array}$ \\
\hline
\end{tabular}




\section{A2: Cost of Doing Business: Definition and Derivation of Indices ${ }^{83}$}

Doing Business measures the regulation of employment, specifically as it affects the hiring and firing of workers and the rigidity of working hours. The data on employing workers are based on a detailed survey of employment regulations that is completed by local law firms. The employment laws of most countries are available online in the NATLEX database, published by the International Labour Organization. Laws and regulations as well as secondary sources are reviewed to ensure accuracy. Conflicting answers are further checked against 2 additional sources, including a local legal treatise on employment regulation.

To make the data comparable across countries, several assumptions about the worker and the business are used.

\section{Assumptions about the Worker}

The worker:

- Is a non-executive, full-time male employee who has worked in the same company for 20 years.

- Earns a salary plus benefits equal to the country's average wage during the entire period of his employment.

- Is a lawful citizen with a wife and 2 children. The family resides in the country's most populous city.

- Is not a member of a labour union, unless membership is mandatory.

83 This overview is taken verbatim from the Cost of Doing Business website, http://www.doingbusiness.org/MethodologySurveys/ EmployingWorkers.aspx 


\section{Assumptions about the Business}

The business:

- Is a limited liability company.

- Operates in the country's most populous city.

- Is 100 per cent domestically owned.

- Operates in the manufacturing sector.

- Has 201 employees.

- Abides by every law and regulation but does not grant workers more benefits than what is legally mandated.

- Is subject to collective bargaining agreements in countries where such bargaining covers more than half the manufacturing sector.

\section{Rigidity of Employment Index}

The rigidity of employment index is the average of three sub-indices: a difficulty of hiring index, a rigidity of hours index and a difficulty of firing index. All the sub-indices have several components. And all take values between 0 and 100, with higher values indicating more rigid regulation.

The difficulty of hiring index measures (i) whether term contracts can be used only for temporary tasks; (ii) the maximum cumulative duration of term contracts; and (iii) the ratio of the minimum wage for a trainee or first-time employee to the average value added per worker. A country is assigned a score of 1 if term contracts can be used only for temporary tasks and a score of 0 if they can be used for any task. A score of 1 is assigned if the maximum cumulative duration of term contracts is less than 3 years; 0.5 if it is between 3 and

5 years; and 0 if term contracts can last 5 years or more. Finally, a score of 1 is assigned if the ratio of the minimum wage to the average value added per worker is higher than $0.75 ; 0.67$ for a ratio greater than 0.50 and less than or equal to $0.75 ; 0.33$ for a ratio greater than 0.25 and less than or equal to 0.50 ; and 0 for a ratio less than or equal to 0.25 . In the Central African Republic, for example, term contracts are allowed only for temporary tasks (a score of 1), and 
they can be used for a maximum of 2 years (a score of 1 ). The ratio of the mandated minimum wage to the value added per worker is 0.66 (a score of 0.67 ). Averaging the three sub-indices and scaling the index to 100 gives the Central African Republic a score of 89.

The rigidity of hours index has 5 components: (i) whether night work is unrestricted; (ii) whether weekend work is unrestricted; (iii) whether the workweek can consist of 5.5 days; (iv) whether the workweek can extend to 50 hours or more (including overtime) for 2 months a year; and ( $v$ ) whether paid annual vacation is 21 working days or fewer. For each of these questions, if the answer is no, the country is assigned a score of 1 ; otherwise a score of 0 is assigned. For example, Montenegro imposes restrictions on night work (a score of 1) and weekend work (a score of 1), allows 5.5-day workweeks (a score of 0), permits 50-hour workweeks for 2 months (a score of 0 ) and requires paid vacation of 20 working days (a score of 0 ). Averaging the scores and scaling the result to 100 gives a final index of 40 for Montenegro.

The difficulty of firing index has 8 components: (i) whether redundancy is disallowed as a basis for terminating workers; (ii) whether the employer needs to notify a third party (such as a government agency) to terminate 1 redundant worker; (iii) whether the employer needs to notify a third party to terminate a group of more than 20 redundant workers; (iv) whether the employer needs approval from a third party to terminate 1 redundant worker; (v) whether the employer needs approval from a third party to terminate a group of more than 20 redundant workers; (vi) whether the law requires the employer to consider reassignment or retraining options before redundancy termination; (vii) whether priority rules apply for redundancies; and (viii) whether priority rules apply for reemployment. For the first question an answer of yes for workers of any income level gives a score of 10 and means that the rest of the questions do not apply. An answer of yes to question (iv) gives a score of 2. For every other question, if the answer is yes, a score of 1 is assigned; otherwise a score of 0 is given. Questions (i) and (iv), as the most restrictive regulations, have greater weight in the construction of the index.

In Tunisia, for example, redundancy is allowed as grounds for termination (a score of 0 ). An employer has to both notify a third party (a score of 1) and obtain its approval (a score of 2) to terminate a single redundant worker, and has to both notify a third party (a score of 1) and obtain its approval (a score of 1 ) to terminate a group of redundant workers. The law mandates consideration of retraining or alternative placement before termination (a score of 1 ). There are priority rules for termination (a score of 1 ) and reemployment (a score of 1). Adding up the scores and scaling to 100 gives a final index of 80 for Tunisia. 


\section{Nonwage Labour Cost}

The nonwage labour cost indicator measures all social security payments (including retirement fund; sickness, maternity and health insurance; workplace injury; family allowance; and other obligatory contributions) and payroll taxes associated with hiring an employee in fiscal year 2005. The cost is expressed as a percentage of the worker's salary. In Bolivia, for example, the taxes paid by the employer amount to 13.7 per cent of the worker's wages and include 10 per cent for sickness, maternity and temporary disability benefits; 1.7 per cent for permanent disability and survivor benefits; and 2 per cent for housing.

\section{Firing Cost}

The firing cost indicator measures the cost of advance notice requirements, severance payments and penalties due when terminating a redundant worker, expressed in weekly wages. One month is recorded as 4 and 1/3 weeks. In Mozambique, for example, an employer is required to give 90 days' notice before a redundancy termination, and the severance pay for workers with 20 years of service equals 30 months of wages. No penalty is levied. Altogether, the employer pays the equivalent of 143 weeks of salary to dismiss the worker.

This methodology was developed in Botero and others (2004) and is adopted here with minor changes. 